\title{
中国・徽州地方の祠堂建築に関する研究 \\ 晾県を中心とする祠堂建築の分類と分布 \\ STUDY ON RITUAL ARCHITECTURE IN HUIZHOU AREA, CHINA
}

The classification and distribution of Ritual Architecture in Shē County

\author{
張 葉 茜*, 杉 野 丞**, 沢田 多喜二*** \\ Yeqian ZHANG, Noboru SUGINO and Takiji SAWADA
}

\begin{abstract}
The subject of this research is making Shē county that is the center of politics, economic and culture of Huizhōu Area to be the target. And the object is elaborate Ritual Archtecture classification, change by history, distribution by region and develop from records of Ritual Archtecture on local records from Sòng Dynasty untill Qīng Dynasty.

1. Classify by worship mode : "Regional Temple" from local beliefs, "Mausoleum" (Grave-worship) and "Ancestral Hall" (Templeworship) for Ancestor Worship.

2. Analysis Ritual Archtecture's distribution and feature, and research Ritual Archtecture's distribution by commerce develop and the Lineage Settlements (villages) develop in Hūzhōu by mark out every Ritual Archtecture's location on map.

3. Discuss Ritual Archtecture's brench and development.
\end{abstract}

Keywords : Hużzhōu Area, Regional Temples, Mausoleum, Ancestral Hall, Local Beliefs, Ancestor Worship 徽州地方，祠廟，墓祠，宗祠，地方信仰，祖先祭祀

\section{1.はじめに}

$1-1$. 研究背景

徽州地方は、中国の揚子江下流域の安徽省南部にあり、浙江省を 流れる新安江の上流域に位置する。徽州の名称は宋代に始まり、䣄・ 休寧・嫯源・市門・績溪・黟の六県からなり、清代に至るまで継承 された。しかし、現在は教源県が江西省上饒市、績溪県が安徽省宣 城市に含まれ、他の四県が安徽省黄山市に属している。

徽州は唐代中期以降、中原地方の戦乱を避け、或は官となって派 遣された人々が黄山の南麓に移住し、先進的な文化や技術を転播さ せ、それらの人々が代々集住して宗族村落を形成した。

宋代以降、徽州の人々は山岳地において耕地の不足が生じたため、 新安江の水運を生かして商売を始め、次第に揚子江へと活路を広げ て富を築き、「徽州商人」として広く知られるようになった。

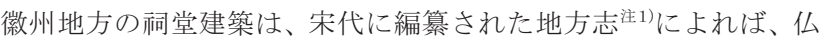
教・道教の宗教施設と区別され、民間信仰として、神々を祀る「祠廟」、 墓地の傍に建てられ、墓主を祀るための「墓祠」などと記載されてい る。また、宗族村落の中には、宗族祖先を祀るために建てた祠堂も あり、明代中期の地方志注 21 には「宗祠」と通称され、記載されるよう になった。このように、宋代から明代までの「祠堂建築」は、官制の「祠
廟」、墓祭の「墓祠」、宗族の「宗祠」が存在していたことが知られてい る。こうした祠堂については、日中両国において関心が寄せられ、 歴史的な文献研究はなされているものの、建築的な枠組や特徵につ いては十分な研究が行われていない。

\section{$1-2$. 既往研究}

近年、徽州地方の祠堂建築をめぐる研究は、様々な方面から行わ れている。その中で代表的な研究は以下の通りである。

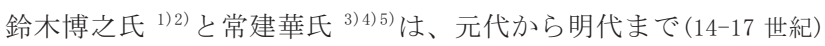
の地方志、族譜などを基に、鈴木氏が宗族の形成、祭祀組織の変化 を論じ、常氏が祠廟、墓祠にみられる宗族の発展、宗祠の形成等を 論じられた。また、井上徹氏 ${ }^{6)}$ 、松本浩一氏 ${ }^{7)}$ 、吾妻重二氏 ${ }^{8)}$ は、 宋代の先進地区であった江南地方の祠堂を対象とし、井上氏が国家 礼制、宗法主義の立場から宗族発展、松本氏が民間信仰の立場から 社から祠廟への変遷を述べ、吾妻氏は文集、小説などから、祭祀対 象、祭祀者について論じられた。しかし、いずれも徽州地方の祠堂 建築については、その一部の事例が取り上げられているのみである。

\section{$1-3$. 研究目的}

祠堂建築については、歴史学、民俗学などの分野において、国家 体制、宗法礼制、宗族制度等の立場から論じられているものの、建
* 愛知工業大学工学部生産建設工学専攻博士後期課程 大学院生

** 愛知工業大学工学部建築学科 教授 . 工博

*** 愛知工業大学工学部建築学科 非常勤講師
Grad. Stud., Dept of Production and Construction Engineering Course, Graduate School of Engineering, Aichi Institute of Technology Prof., Dept. of Architecture, Aichi Institute of Technology, Dr.Eng.

Lect., Dept. of Architecture, Aichi Institute of Technology 
築史学の分野では祠堂建築の分類や形成過程を大系的に分析・検討 した論考は少ない。そのため、現在数多く残される祠堂建築の遺構 について歴史的な経緯と建築的な発展を合せて理解することは困難 な状況である。そこで、本稿では徽州地方の政治・経済・文化の中 心地であった龵県を対象とし、宋代から明・清代にかけて地方志に 記される祠堂建築の分類と分布、さらに、分化と発展の一端を明ら かにすることを目的とする。なお、この地方の祠堂建築の遺構につ いては、別稿で取り上げて建築的な特質を明らかにしたい。

\section{$1-4$. 研究方法}

徽州地方の地方志は、宋代から始まり、それ以前の歴史について は国史、風土紀、地理志等を基に、その概要が記されている。明代 に入ると編纂が盛んになり、徽州府下の六県の地方志が刊行されて いる。徽州地方における主な地方志は、『新安志』(宋: 淳熙)、『徽州 府志』(明: 弘治・嘉靖、清: 康熙・道光) ${ }^{14)}$, 注3)であり、歎県志としては、 『歎志』(明: 万暦 $)^{15}$ 、『䣄県志』(清: 乾隆・道光 $)^{14)}$, 注3) が挙げられる。 そこで、これらに取り上げられた祠堂の巻数と分野を分析し、祠堂 の分類と信仰形態さらに分布と発展過程について検討する。

\section{1-5. 対象地域}

徽州地方の祠堂建築の全体像を解明するためには、文献史料と共 に祠堂建築の遺構の残存状況を把握することが求められる。そこで、 『黄山市徽州古建築保護工程名録』(2014 刊 $)^{12}$ 、『中国文物地図集一 安徽分册』(2014 刊 $)^{13)}$ について、その数を取り上げてみると、(図 1 ・ 附表)ように、前述の徽州の中心地であった龵県が 251 棟( 㪘県十徽州 区) と最も多くの遺構を残していることが分る。

歎県は、秦代に新安江の上流域に開かれ、歴代王朝の統治下で領 土の併合、分離が行われ、唐代には県としての領域が定まった。宋 代には徽州府 (徽州の首府) が湌県領内に設けられ、㪘県官衙と共に建 設された。『徽州府志』(明嘉靖)によると、徽州府城を中心として「東 西百五十七里、南北二百四十里」(明代里＝約 $576 \mathrm{~m}$ ) とあり、その後、 近代に至るまで大きな変化はない。但し、中華人民共和国が成立し た 1949 年以降、(図 1$)^{\text {注4) }}$ のように破線で囲まれた北西側の一部が 徽州区、西側の一部が旧休寧県の屯溪区となった。本稿で扱うのは、 唐代から清代までの旧㪘県(網掛け) 地域である。

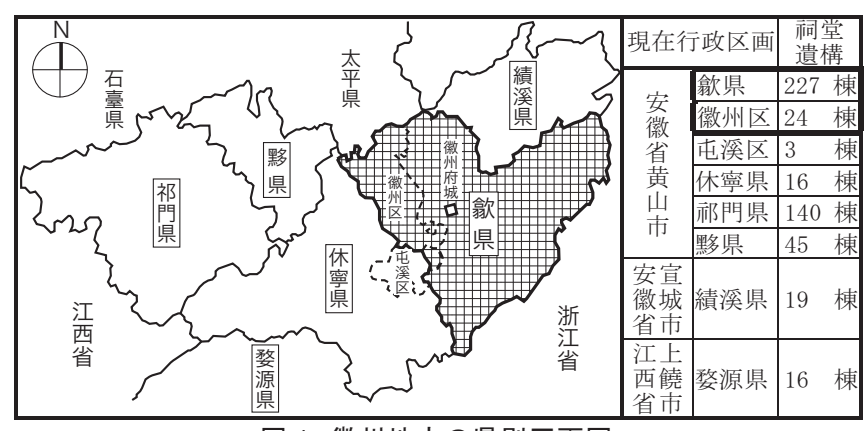

図 1 徽州地方の県別区画図

（附表 徽州地方の祠堂建築 [文物]の遺構数）

\section{2. 徽州の地方志について}

\section{$2-1$. 祠堂と巻数・項目}

徽州地方の地方志は、概衫紀伝体で編纂されている。宋代淳熙二 年(1175)の『新安志』(新安:徽州の古名) は、地域 (州郡、各県) ごとに掲載 され、各地域の沿革、風俗、戸数など様々な内容が含まれている。 しかし、明代以降の府志や県志をみると、いずれも分野別に分けら
れ、各分野の事例が地域別に列挙されている。

そこで、徽州地方の主たる地方志である『新安志』(1 冊)、『徽州府 志』(4 冊：「弘治府志」「嘉靖府志」「康熙府志」「道光府志」)、『豛県志』(3 冊 「万暦県志」「乾隆県志」「道光県志」についてみると、編纂年代によって 祠堂の取り上げ方に差異があるものの、(表 1 ) のように明代以降の 府志や県志では、所属する分野が定まり、祠廟が祀典 (壇廟、秩祀) 篇、墓祠が丘墓篇と寺観篇、宗祠が宮室篇に掲載されていることが 分る。なお、本稿の対象地域となる龵県は、宋代から領内に徽州首 府 (宋: 州郡、明・清:府) が設置されたため、地方志から事例を取り上 げる際には、徽州府と㰸県の管轄範囲の両方を扱った。

表 1 地方志の祠堂と巻数 $*$ 分野

\begin{tabular}{|c|c|c|c|c|c|c|c|c|c|c|c|c|}
\hline & \multicolumn{4}{|c|}{ 新安志 } & \multicolumn{4}{|c|}{ 徽州府志 } & \multicolumn{3}{|c|}{ 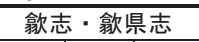 } & \\
\hline 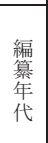 & \multicolumn{4}{|c|}{ 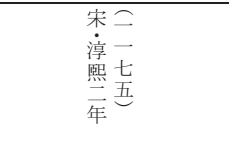 } & $\begin{array}{l}\text { 明 } \\
\text { 弘五 } \\
\text { 治兑 } \\
\text { 吾 } \\
\text { 年 }\end{array}$ & 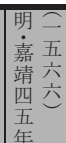 & $\begin{array}{l}\text { 清气 } \\
\text { 康交 } \\
\text { 㹂九 } \\
\text { 分九 } \\
\text { 年 }\end{array}$ & $\begin{array}{l}\text { 清乞 } \\
\text { 道八 } \\
\text { 光立 } \\
\text { 年 }\end{array}$ & \begin{tabular}{|l} 
明 \\
方六 \\
曆。 \\
妄旮 \\
年
\end{tabular} & \begin{tabular}{|l} 
清 \\
乾七 \\
隆七 \\
亲 \\
年
\end{tabular} & $\begin{array}{l}\text { 清 } \\
\text { 道公 } \\
\text { 光尣 } \\
\text { 年 }\end{array}$ & 堂 \\
\hline 略 & \multicolumn{4}{|c|}{$\mid$} & $\begin{array}{l}\text { 弘腐 } \\
\text { 治 }\end{array}$ & 益腐 & 康腐 & \begin{tabular}{|l} 
䆃碓䓌 \\
\end{tabular} & 磨罢 & $\begin{array}{l}\text { 乾県 } \\
\end{array}$ & 道県 & 別 \\
\hline \multirow{4}{*}{$\begin{array}{l}\text { 数 } \\
* \\
\text { 分 } \\
\text { 野 } \\
\text { 篇 }\end{array}$} & $\begin{array}{l}\text { 第 } \\
\text { 䖭 } \\
\text { * } \\
\text { 州 } \\
\text { 郡 } \\
\text { * } \\
\text { 祠 } \\
\text { 朝 }\end{array}$ & 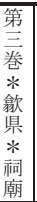 & 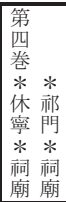 & 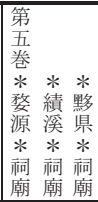 & $\begin{array}{l}\text { 巻 } \\
\text { 辛 } \\
\text { 范 } \\
\text { 跑 } \\
\text { 典 }\end{array}$ & 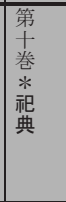 & 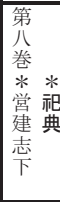 & $\begin{array}{l}\text { 巻 } \\
\text { 卷 } \\
* * \\
\text { 黨 壇 } \\
\text { 䓌 } \\
\text { 上 }\end{array}$ & 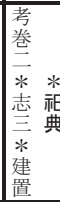 & 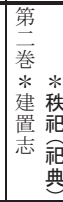 & 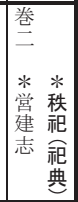 & $\begin{array}{l}\text { 祠 } \\
\text { 廟 }\end{array}$ \\
\hline & & $\begin{array}{l}* * \text { 兵 } \\
\text { 墓 }\end{array}$ & I & | & $\begin{array}{l}\text { 巻 } \\
\text { 美 } \\
\text { * } \\
\text { 地 } \\
\text { 兵 } \\
\text { 墓 }\end{array}$ & $\begin{array}{l}\frac{\text { 第 }}{\frac{7}{7}} \\
\text { 巻 } \\
\text { 采 } \\
\text { 幕 }\end{array}$ & 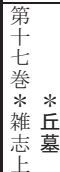 & 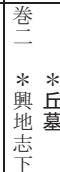 & 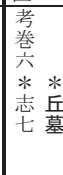 & 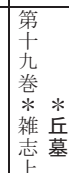 & 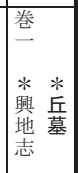 & \\
\hline & & $\begin{array}{l}\text { 檤 } \\
\text { t }_{\text {U }}\end{array}$ & 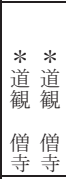 & 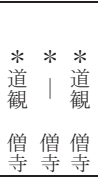 & $\begin{array}{l}\text { 巻 } \\
+ \\
+\end{array}$ & 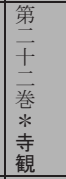 & 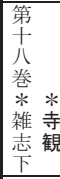 & 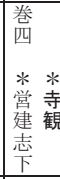 & $\begin{array}{l}\text { 考 } \\
\text { 粪 } \\
\text { 䓌 } \\
\text { 志 } \\
\text { 七観 }\end{array}$ & 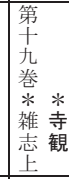 & 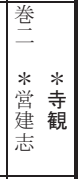 & 祠 \\
\hline & 1 & I & I & | & * & $\begin{array}{l}\overline{+} \\
\text { 巻 }\end{array}$ & I & I & I & I & 1 & \begin{tabular}{|l} 
宗 \\
谅
\end{tabular} \\
\hline
\end{tabular}

\section{2-2. 祠堂の分野と内容}

祠廟、墓祠、宗祠について、前掲(表 1 ) の明代の「弘治府志」、「嘉 靖府志」を取り上げ、祠堂の分野と内容を検討してみよう。

(1) 祀典篇には、壇と祠廟が掲載されている。両者は国家祭祀の体 系の中に位置づけられ、壇の祭祀は地方官衙が祭官となり、神々へ の奉仕が行われ、その建設・修繥の経費も官衙から支出された。また、 祠廟は国家に公認された地方信仰の祭祀場であり、その維持は一般 信者の支援に頼っていたが、地方官衙が春・秋祭りに参加し、修繥、 祭祀の費用を支給することもあった。建築的には、壇とは露天の祭 祀場であり、壁のない場所に位牌などを置いて祀るのが原則である。 上は国都の天壇、地壇から、各府・県の社稷壇、風雲雷雨山川壇、さ らに各里の里社壇に至るまである。それに対し、祠廟は建造物であ り、その中には祭祀の対象となる尊像が置かれるのが一般的である。 （2）丘墓篇には、地域に影響を与えた人物の墓が記載され、その中 には、「越国汪公墓の傍に墓祠がある」など墓䰚に関する記載がある。 （3）寺観篇は、仏教・寺院、道教・宮観のことであり、その中に、 「崇福寺の中に金氏夫人墓と祠を建て」、「鮑景山墓を管理・祭祀す るために南極観を営む」など墓祠に関する記載がある。

(4) 宮室篇は、古漢語では住宅建築を指寸「宮室」注5) が用いられ、 
宗教建築の寺観などと区別され、宅・亭・楼などの民間建築として 扱われ、宗祠は祖先祭祀の建物として列挙されている。また、宮室 篇は清代康熙年間以降の府志や県志には載せられていないが、「康熙 府志」第八巻*営建志下によると、「子孫建以祀先世者概從略」とあ り、明代中期以降に宗祠のような祖先祭祀の施設が大幅に増えたこ とから、地方志への記載が省略されるようになったと見られる。

\section{3. 徽州地方と禀県の地域性について}

\section{3-1. 移民と商人}

徽州は古来、越または百越と称され、秦代に入ると中原の王朝に より統治された。この地域の住民は、前述のように漢代から唐・宋・ 元代にかけて中原から移り住んだ移民と土着民から構成された。そ こで、前掲(表 1 ) の「嘉靖府志」の第一巻*廂隅郷都 (人口)上り、徽 州における歴代の移住各姓ならびに戸数と人口の統計を取り、時代 による変化を眺めてみたい。（表 2 )を見ると、徽州への移住の第一 波は晋代であり、永嘉の乱(307-312)の際、程、鮑、俞などの姓の一 族が徽州に移住し、最も早期の戸数は西晋太康初(280-) の五千戸で ある。第二波は唐代の安史の乱 (755) から、范、鄭、洪、吳など大量 の一族が移住すると、唐の貞観から天宝年間 (627-756) までに戸数が 6. 3 倍、人口が 10 倍に増加したことが分る。この他、元代にも多く の人々が流入し、人口が急増加したことが窅える。

中でも、注目すべきは、元代に約 91 万と記録されている人口が明 洪武二十四年 (1391) に約 58 万まで急激に減少していることである。 これは、元代から明代にかけて転換期を迎え、元代以降の耕地が飽 和点に達し、多くの人々が客商として外地に赴き、次第に新たな土 地に定住し、或は籍を移したものと考えられる注 6 )。さらに、徽州商 人は新安江と揚子江ならびに京杭大運河などの水路を利用し、商業 を各地に発展させたとみられている。また、明代後半には徽州地方 の人々の農業への依存度が少なくなり、七割から九割が商業で生計 を立てていたことが指摘されており注7)、明代の嘉靖四十一年 (1562) には戸数が約 11 万となり、戸数・人口の増加が認められる。

表 2 徽州における各姓の移住時期と同期の戸数

\begin{tabular}{|c|c|c|c|c|c|c|c|c|c|c|c|c|c|}
\hline $\begin{array}{l}\text { 時 } \\
\text { 代 }\end{array}$ & 漢 & 晋 & $\begin{array}{l}\text { 南 } \\
\text { 朝 } \\
\text { 梁 }\end{array}$ & 隋 & \multicolumn{2}{|c|}{ 唐 } & \begin{tabular}{|l} 
五 \\
代
\end{tabular} & $\begin{array}{l}\text { 北 } \\
\text { 宋 }\end{array}$ & $\begin{array}{l}\text { 南 } \\
\text { 赑 }\end{array}$ & 元 & \multicolumn{3}{|c|}{ 明 } \\
\hline $\begin{array}{l}\text { 移 } \\
\text { 集 } \\
\text { 各 } \\
\text { 姓 } \\
\text { ב }\end{array}$ & $\begin{array}{l}\text { 舒 } \\
\dot{3} \\
\dot{3} \\
\dot{\text { 汪 }}\end{array}$ & $\begin{array}{l}\text { 鮑 戴 } \\
\text { 俞 } \\
\\
\text { 余 } \\
\text { 黄 } \\
\text { 程 } \\
\text { 葉 }\end{array}$ & \begin{tabular}{|c} 
任 \\
閔 \\
徐 \\
\end{tabular} & $\begin{array}{l}\text { 謝 } \\
\text { 詹 }\end{array}$ & \multicolumn{2}{|c|}{ 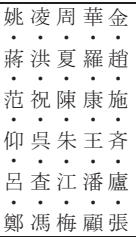 } & $\begin{array}{l}\text { 邵 } \\
\text { 項 } \\
\text { 許 } \\
\text { 胡 } \\
\text { 故 } \\
\text { 何 } \\
\text { 李 }\end{array}$ & 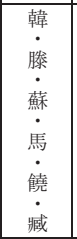 & $\begin{array}{l}\text { 余 } \\
\text { 荘 } \\
\text { 杜 } \\
\text { 葛 } \\
\text { 章 } \\
\text { 游 }\end{array}$ & $\begin{array}{l}\text { 田 } \\
\text { 仇 }\end{array}$ & \multicolumn{3}{|c|}{$\begin{array}{l}\text { 不 } \\
\text { 詳 }\end{array}$} \\
\hline $\begin{array}{l}\text { 年 } \\
\text { 代 }\end{array}$ & | & 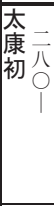 & & $\begin{array}{l}\text { 開 } \\
\text { 皇五 } \\
+\frac{\text { 九 }}{\text { 年 }}\end{array}$ & $\begin{array}{l}\text { 貞 } \\
\text { 観六 } \\
\text { 年云 } \\
\text { 間七 } \\
\text { 六 } \\
\text { 酉 } \\
\text { 卆 }\end{array}$ & \begin{tabular}{|l} 
天 \\
宝旨 \\
年四 \\
間市 \\
㫐 \\
童
\end{tabular} & | & 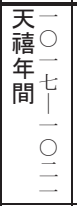 & $\begin{array}{l}\text { 嘉二 } \\
\text { 定二 } \\
\text { 万端 } \\
\text { 平 } \\
\text { 年二 } \\
\text { 間三 } \\
\text { 公 }\end{array}$ & 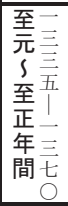 & $\begin{array}{l}\text { 洪二 } \\
\text { 武云 } \\
\text { 艺 } \\
\text { 四 }\end{array}$ & $\begin{array}{l}\text { 弘二 } \\
\text { 治四 } \\
\text { 吾光 } \\
\text { 年 }\end{array}$ & $\begin{array}{l}\text { 嘉二 } \\
\text { 靖五 } \\
\text { 四六 } \\
+\frac{1}{\text { 年 }}\end{array}$ \\
\hline 戸数 & - & 5000 & - & 6154 & 6021 & 38320 & 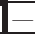 & 127203 & 101278 & 178875 & 131662 & 96189 & 114197 \\
\hline 人口 & - & - & - & - & 26617 & 269109 & & 192292 & - & 910698 & 581082 & 557355 & 566397 \\
\hline
\end{tabular}

\section{3-2. 宗族と集落}

(1) 宗法と宗族

周代の宗法は、身分制度を定め、上から天子・諸侯・大夫・土・ 庶民とされた。身分相続では、嫡子が父の身分を継ぐのに対し、庶 子はすべて臣下に下り、嫡子と分かれて一家を創設するが、分家し
た庶子は後世子孫の祖として祀られた。そして、嫡系の子孫が「大 宗」、庶系の子孫が「小宗」と呼ばれ、大宗と小宗は、本家と分家の 関係にあたる注 8)。漢代以降、宗法は礼制面のみでなく、官制・法律 等を整備する上で重大な役割を果たした。宋代に入ると、当時の社 会・政治に関する『周官』、『周礼』等の宗法典籍に関する新たな注 釈が作られた。中でも、『家礼』16)、注 9) は家族の儀礼・作法を示した ものであり、これを編纂した朱喜(宋 1130-1200) は、徽州袑源県の出 身であり、儒学の中興と呼ばれ、朱子学の創始者となった。

『家礼』によれば(図 2 ) 注 10) のように、一族の中に宗族・家族の 概念が生まれ、宗族とは、ある地域による家系を遡ると最初の祖先

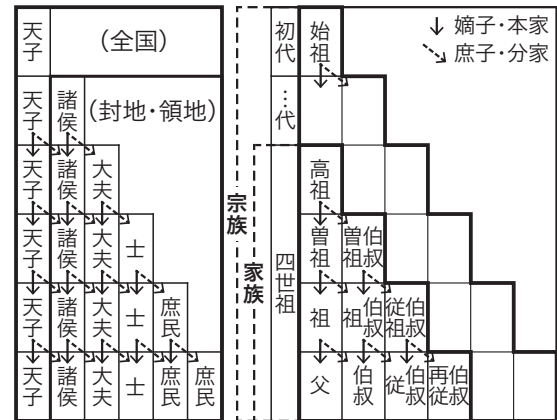

図 2 身分相続モデルと大宗小宗図
(始祖)を持ち、家族と は、四世祖 (高・曽・ 祖・父)を共通に持つ、 同一姓の血縁集団で ある。つまり、家族 が宗族に含まれ、宗 族の祭祀対象となる 祖先の範囲が広がる ことを意味する。

(2) 宗族村落と戸数・人口

明・清代には、朝廷は社会全体の管理を行うために、城内と城外 に廂隅制 (城外: 関廂、城内: 隅)、農村部に郷都制とする「村落制度」を 布き、戸数と人口を掌握していた。村落とは、旧来の自然発生的な 集落を指寸が、徽州地方には一族が代々同居して形成された宗族村 落が数多く残されている。但し、宗族村落の中には、他姓の移住、 婚姻関係等により、小数の他族が含まれていたようである。

ここでは、前掲の地方志から以下のア〜才.を取り上げ、明代嘉靖 四十五年 (1566) から清道光八年 (1828)までの 262 年間における歌県 地方の村落数・戸数・人口を取り上げ、村落の平均戸数・人口など を集計すると(表 3 ) のようになる。

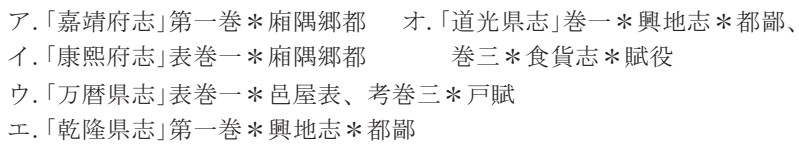

表 3 舒県の戸数 - 人口と村落数

\begin{tabular}{|c|c|c|c|c|c|c|}
\hline 出典 & $\begin{array}{l}\text { 嘉靖 } \\
\text { 府志 }\end{array}$ & $\begin{array}{l}\text { 万暦 } \\
\text { 県志 }\end{array}$ & $\begin{array}{l}\text { 康熙 } \\
\text { 府志 }\end{array}$ & $\begin{array}{l}\text { 乾隆 } \\
\text { 県志 }\end{array}$ & $\begin{array}{l}\text { 道光 } \\
\text { 県志 }\end{array}$ & \multirow{2}{*}{$\begin{array}{l}\text { 増幅 } \\
\text { 倍率 }\end{array}$} \\
\hline 刊行年代 & 1566 & 1609 & 1699 & 1771 & 1828 & \\
\hline 総戸数 & 39922 & 62131 & - & - & 114950 & 2.88 倍 \\
\hline 総人口 & 204000 & 二 & 二 & - & 617111 & 3.03 倍 \\
\hline 隅・村落 & 19 & 18 & 18 & 18 & 48 & 2.53 倍 \\
\hline 関廂・村落 & 28 & 35 & 34 & 35 & 94 & 3.36 倍 \\
\hline 郷都・村落 & 262 & 265 & 279 & 626 & 1408 & 5.37 倍 \\
\hline 総村落 & 309 & 318 & 331 & 679 & 1550 & 5.02 倍 \\
\hline 戸数/村落 & 129 & 195 & - & - & 74 & 0.57 倍 \\
\hline 人口/村落 & 660 & 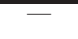 & . & - & 398 & 0.60 倍 \\
\hline 人口/戸 & 5 & - & - & - & 5 & - \\
\hline
\end{tabular}
歌県の総戸数と 総人口は、この 262 年間で 2.88 倍 と 3.03 倍の増加を 示し、総村落数も 5.02 倍に増加して いる。しかし、村 落数は、清代康熙 年間以前には、明 らかな増加が見当 らない。それに対し、乾隆年間以降、城内(隅) ・城外(関廂) ・ 農村部(鄉 都)において、村落数が増加し始め、特に、郷都にできた新村落の数 (1408 所)が際立っている。また、明代万暦年間の総村落(318 所)に対 する総戸数(62131戸)の割合を求めると、一つの村落に 195 戸が住み、 明代末の戸口増加に伴う村落の過密化が始まり、分家による周辺地 域一の転居によって新たな村落が生まれたと考えられる。このよう 
な宗族村落の増加が、䣄県において数多くの祠堂が建設される背景 となったと見られる。

\section{3-3. 地方信仰}

中国の地方信仰は、古代の社の自然崇拝から始まり、時代が下る と、人・鬼などが神格化されたものが多く、後漢末には人格神を祀 った祠廟が現れた ${ }^{\text {i玉 }}{ }^{11}$ 。地方神の中には、地域を超えて広い地方で 信仰された神々があり、例えば、宋代に全国で祀られた江西と徽州 袑源県を起源とする五顕神、湖州広徳軍の張大帝への信仰などがそ れにあたる。徽州地方では、地方志などによると、この地で暮らす 宗族の祖先が神格化され、地方信仰の源になったとされ、その中で、 欴県の代表的なものを挙げると以下の通りである。

（1）徽州の方儲（-93）は、方氏の始祖とされ、易経、占筮に精通し ていたため、神に通ずる力のある人物とされ、彼を祀る祠廟を仙翁 廟 (方储廟、真応廟) と呼んだ注 ${ }^{2}$ )。早期の仙翁廟は、後漢に「杽之東郷」 (今浙江省淳安県) の墓所に建てられ、彼の修行場 (䣄県・柳亭山)にも建 てられ、これが徽州地方の最初の祠廟と考えられている。

(2) 徽州の汪氏は、漢代に移住しているが (表 2 )、隋末新安の豪族 汪華(578-649) は、隋を滅したことに功労があったとされ、唐より越 国公の称号を賜わり、歎、宣、杭など六州の統治を任され、これが 徽州汪氏の事実上の起源となる。汪華死後、徽州各地には様々な祠 廟が建設され、中でも、汪華の挙兵地(㪘県) と旧都(績溪県) に建てら れたものが多く、皇帝より「忠顕」「忠烈」などの廟額が冊封される と、民間では「汪王廟」と称された注 ${ }^{13)}$ 。

(3) 徽州の程氏は、晋代の新安太守の程元譚(245-322) と南朝梁の将 軍の程霊洗 (514-68) を祖としており、特に、程霊洗は後世に神格化 され、徽州各地において世忠廟や世忠行呞として祀られ、中でも彼 の旧宅と墓(䣄県・筀墩)の傍に建てられた世忠廟が本山とされた注 14 )。

\section{$3-4$. 祖先祭祀}

祖先祭祀は、明代の「嘉靖府志」第二巻*風俗篇によると、墓所で 遺体を祀る墓祭式、廟を建てて位牌を祀る廟祭式の二つがある。

（1）墓祭式は、墓の傍に墓主を祀る伝統的な「墓祠」であり、漢代(紀 元前 202-後 220)に一度盛行したが、魏晋時代(184-589) 以降、衰え始め る 注 ${ }^{15)}$ 。徽州地方の墓祭式は、朱喜(南宋 1130-1200)の『家礼』の礼 制に倣うことと定められたが、仏教や道教の儀式の影響を受けたも のが多かったとされる。

(2) 廟祭式(袷祭式) は、儒教の影響を受けたと考えられる。宋代以 前には、祖先を祀る廟は皇族・官僚・貴族に限られ、身分に応じて 廟を建てたが、庶民は居室の中に祖と父のみ祀り、廟の建設が許さ れなかった注 16)。宋代に入ると、程頣(1033-1107) らは、始祖の祭祀 と始祖から分れた子棌の全てが集合する大宗主義を提唱したが、社 会に広く影響を与えたのは、朱喜(1130-1200)による四世祖を祀る祭 祀形式であり、居室の傍に「祠堂」という建物を建てて家の範囲の 親族を集める小宗主義に基づくものであった注 ${ }^{17)}$ 。元代以降、宗族 の組織化が推し進められ、徽州地方では、特に移民の移住・開発と 村落の生成を背景に、方孝儒(1357-1402) は同じ土地(村落)に居住して いた者を対象とし、始遷祖というその土地に最初に移住した祖先の 祭祀、ならび族譜の編纂や宗祠の建設を行うことで、宗族相互の結 束を固める事業を推進した注 ${ }^{18)}$ 。また、明代の嘉靖年間の礼制改革注 ${ }^{199}$ により、徽州地方の地方志にも宗祠に関わる記述が加わり、「嘉靖 府志」の宮室篇に登場しすることになった。

\section{4. 祠堂建築の分類について}

\section{4-1. 欴県の祠堂建築の事例区分と一覧表 (表 4)}

ここでは、徽州地方の宗族が形成・組織化される中で、宋代から 明代中期前半までの祠堂建築の類型と特徽を検討し、それらの時代 的な推移を眺めてみたい。前掲の「新安志」(1175)、「弘治府志」(1502) を対象とし、「新安志」第一巻*州郡*祠廟篇、第三巻水龵県 $*$ 祠廟 篇、「弘治府志 $\rfloor$ 巻之五 $*$ 祀典篇、巻之二 $*$ 地理二*丘墓篇、巻之十 *寺観・宮室篇の中から、龵県と徽州府の祠堂建築の事例を全て取 り挙げた。但し、自然神の城隍神、泰山、龍王、人格神の関羽、張 大帝、儒家先聖など䣄県が起源でない事例は省略した注 20 )。

そこで、「新安志」の 4 例、「弘治府志」の 43 例について(両志の同一 事例は一行に記載)、前掲の (表 1 ) の祠堂建築の分野と内容、地方信仰 と祖先祭祀の区分を考慮し、次のような枠組で検討してみたい。

\begin{tabular}{|c|c|c|c|c|c|c|c|}
\hline \multirow{4}{*}{ 新 } & 祠廟篇 & \multirow{4}{*}{$\begin{array}{l}\text { 咍 } \\
\text { 奀 }\end{array}$} & 祀典篇 & 地方信仰の事例 & 祠廟 & - & 表 $4 \cdot$ ・上段 \\
\hline & - & & 乓墓篇 & \multirow{3}{*}{ 祖先祭祀の事例 } & 墓祠 & \multirow{2}{*}{ 墓祭式 } & \multirow{2}{*}{ 表4・下段 } \\
\hline & - & & 寺観篇 & & 墓祠 & & \\
\hline & - & & 宮室篇 & & 宗祠 & 廟祭式 & 表 4 •下段 \\
\hline
\end{tabular}

さらに、これらの事例がどのような経緯で創設されたのか、地方 志から創建、再建、修繥年代、祭祀対象、建設者、祈禱霊験などの 記録を取り上げると、後掲の（表 4)のようになる。

\section{4-2. 地方信仰の事例}

祠廟は、一般に祠と廟を指すが、地方志では(表 4 ・上段)のよう に、「祠」、廟」、「行祠」、生祠」と祀典篇に記載されるので、その名 称に応じて祠、廟、行祠、生祠の四種類に分類した。祭祀対象は、 いずれも各時代に功績を残し、当地の出身者で社会的に功労のあっ た人物、例えば、官僚、学者、忠義を働いた者などである。建設者 は、民衆、祭祀対象とゆかりのある弟子、後輩、僧侣、子孫、一族 の人々、官衙等である。

(1) 廟の 13 例は、祭祀対象が神格化して祀られるものであり、唐か ら宋代に大半が創建され、建設者が分っているものは民衆の場合が 多い。祠と比べると、「祈禱霊験」、「賜額・賜号」の記載が多くある。 祈禱霊験とは、2. 忠烈廟では凶事を避けたこと、9.忠護侯廟では水 害・干害を回避したことなどであり、賜額・賜号 $[\boldsymbol{十}$ 印 $]$ とは廟額・ 封号の下賜であり、中には複数下賜されたものもあり、朝廷による 認可・保護の象徵である。後掲の (表 4 ・ 上段)、4. 忠助八侯廟、 10. 英烈廟は、廟の創建と賜額・賜号が同時に行われた場合であり、朝 廷より祭祀対象への褒賞・記念の意味があった。一方、民衆によっ て自発的に建設された専祠や専廟注 ${ }^{21}$ は、1. 方儲廟、2. 忠烈廟、3. 飛布廟、8. 世忠廟、9. 忠護侯廟等があり、朝廷が民営の専祠・専廟 の霊験に対して廟額・封号を下賜し、公認の廟として国家祀典に加 えられたと考えられる。

（2）行祠の 7 例は、廟の一種として、“2. 忠烈廟と $23 \sim 28$. 忠烈行祠”、 “8. 世忠廟と 29. 世忠行祠” のような本末関係にあり、本山以外の廟 は行祠と呼ばれた。

（3）祠の 9 例は、前述の廟と比べると、祭祀対象の神格化の信仰か ら変化し、地方名士の表彰、民衆の教化を行う記念的なものが多く なった。また、22. 諫議祠のような子孫が祖先を尊ぶために建てたも のもあった。また、祠の名称は、18. 介庵先生祠、20. 程都憲祠等の ように、祭祀対象の生前の称号により命名することが一般的である。 (4) 生祠の 2 例は、祠の一種として、祭祀対象の生前に建てられた ものであり、30. 知郡寺丞劉公生祠、31. 郡守孫公生祠がある。 


\section{4-3. 祖先祭祀の事例}

祖先祭祀の 12 例は、いずれも「弘治府志」に記載されている。前述 の「墓祭式」と「廟祭式」に区分すると (表 4 ・下段)のようになる。

（1）墓祭式の事例は、宋・元代に創建され、墓主個人を祀るものが 主となる。その中に官衙が創立して子孫が再建するものがあり (32. 程元鳳墓斉、35. 越国公墓祠)、これは官衙が墓主の功績を世に顕すため に創立し、その後、祖先祭祀の形へ変更したものと考えられる。

ア）寺観篇の墓祠は、宗教施設に付随した新たな墓祠であり、宗 教の儀式を行う墳寺・墳庵が墓祠になったと見られる。例えば、 32 . 程元鳳墳寺 (積慶寺) は、朝廷の意向に従って建てられた仏教寺院で あり、33. 鮑氏墳庵(南極観)は、墓主が生前に自分の生墓の傍に営ん だ道教の庵である。その他、34. 金氏夫人墓祠のように、既存の仏教 寺院 (崇福寺)の中に造られ、仏寺の附属施設と寸るものもあった。 イ）丘墓篇の墓祠は、35. 越国公墓祠があり、これは宗教施設によら ない伝統的な墓祠である。
（2）廟祭式の事例は、宮室篇に記載されている。明代の宗族の形成・ 組織化に伴い、祭祀対象により「小宗」(小宗主義) と「大宗」(大宗 主義) とに区別され、小宗は『家礼』において一家族を中心とする四 世祖とされ、大宗は宗族の共通の祖先とされ、四世祖だけではなく、 その以前の先祖、始遷祖、始祖なども祀る。これらの事例は小宗主 義の 40. 慈恩堂を除き、宋代から明代にかけて、「庵、堂、祠堂」な ど大宗主義の事例の増加が認められる。

ア）庵は、地方志によると、宋代に子孫の個人が営んだ祖先祭祀 の建物である。イ）堂は、徽州では一般的に民間住宅を指すが、こ こでは子孫が宗族組織へ住宅を寄進し、祖先祭祀を行なう場合と考 えられる注 22)。庵と比べると創建年代が新しい。ウ）祠堂は、明代の 42.吳氏祠堂、43.陸氏祠堂があり、『家礼』の祠堂と違い、子孫と一 族の人々が共同して創立し、宗族的な祭祀が行われていたことを示 している。このように、庵・堂から祠堂への転換は、宗族思想の影 響により、宗族による祠堂への志向が強まったことを意味する。

表 4 㖨県における宋代〜明代中期前半の祠堂建築の一覧（「新安志 $\lrcorner 4$ 例、「弘治府志 $\lrcorner 43$ 例）

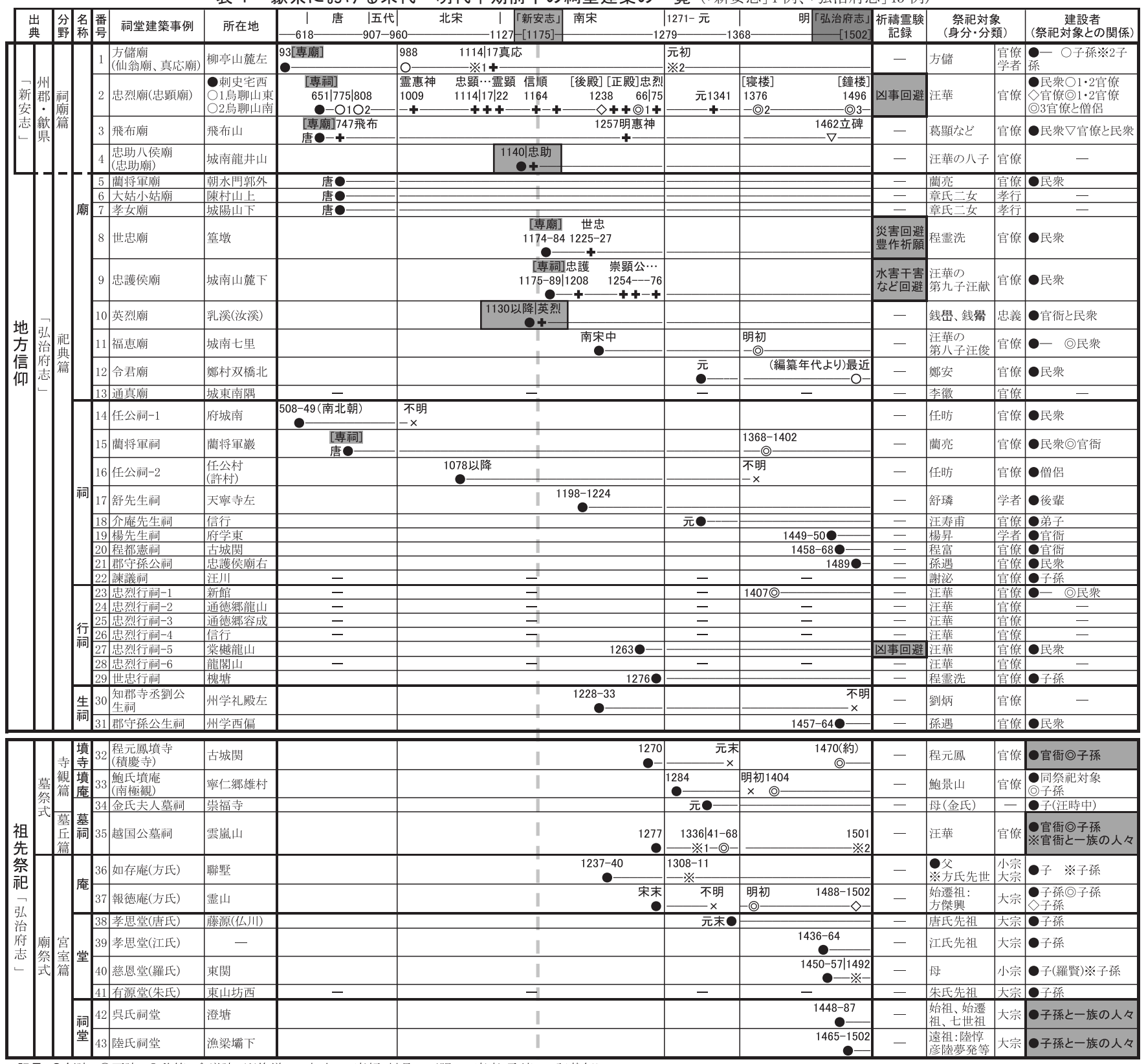

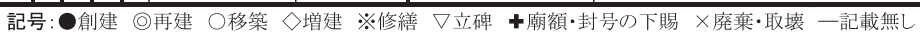


5. 祠堂建築の分布について

5-1. 勯県の祠堂建築事例の一覧表 (表 5)

前述したように、徽州の人々は、宋代以降とりわけ明代中期後半 の嘉靖年間 (1522-66) 以後、水運によって商業の販路を広げて富を蓄 え、また、朝廷の礼制改革なども推し進められ、徽州府を中心とす る㸧県には数多くの祠堂建築が建てられるようになった。そこで、 明代の祠堂建築について、明代中期前後の「弘治府志」の 43 例、「嘉 靖府志」の 110 例を取り上げ、それらの分布を検討するために（表 5 ） を作成した。（表 5 ）の縦列は城郷を示し、横列は 2 つの時代の同一 事例と判断されるもので、名称や分野が違っても、地方志の記述か ら実体が同じと判断されるものは同一事例(綱掛) として扱った。

祠堂建築が所在する土地や村落の区分は、嘉靖年間の「村落制度」

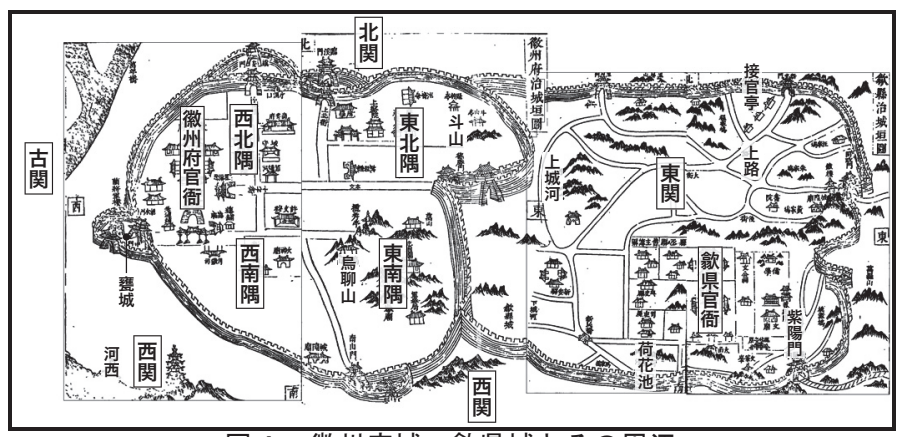

図 4 徽州府城・欴県城とその周辺

表 5 畒県における明代中期前半〜同後半の祠堂建築の一覧 (「弘治府志 $\lrcorner 43$ 例、「嘉靖府志」110 例) (同一事例 33 例)

\begin{tabular}{|c|c|c|c|c|c|c|c|c|c|c|c|}
\hline \multicolumn{3}{|c|}{ 所在地 } & \multicolumn{5}{|c|}{ 「弘治府志」(1502) } & \multicolumn{4}{|c|}{ 「嘉靖府志」(1566) } \\
\hline 郷都 & 関隅都 & T地名村落名 & - & & 例(表4番号付き) & 分野 & 名称 & 氏 & 事例 & 分野 & 名称 \\
\hline \multirow{9}{*}{$\begin{array}{l}\text { 徽 } \\
\text { 州 } \\
\text { 府 } \\
\text { 城 } \\
\text { 内 }\end{array}$} & 東南隅 & \begin{tabular}{|l|} 
城東南隅 \\
烏聊山 \\
太子堂前
\end{tabular} & $\begin{array}{l}\text { 李 } \\
\text { 注 }\end{array}$ & \begin{tabular}{c|}
13 \\
2
\end{tabular} & \begin{tabular}{|l|} 
通息烈廟 \\
\end{tabular} & $\begin{array}{l}\text { 祀典 } \\
\text { 祀典 }\end{array}$ & $\begin{array}{l}\text { 廟 } \\
\text { 廟 }\end{array}$ & $\begin{array}{l}x \\
\text { 汪 } \\
\text { 陶 }\end{array}$ & \begin{tabular}{|l|} 
\\
忠烈廟 \\
陶公词
\end{tabular} & \begin{tabular}{|c|}
$x$ \\
祀典 \\
叔典
\end{tabular} & $\begin{array}{l}x \\
\text { 廟 } \\
\text { 就 }\end{array}$ \\
\hline & 西南隅 & $\begin{array}{l}\text { 城隍廟左 } \\
\text { 城隍廟右 } \\
\text { 新安衞府内 } \\
\text { 東山坊西 } \\
\text { 新安衞前 }\end{array}$ & 朱 & 41 & 有源堂 & 宮室 & 堂 & \begin{tabular}{|l} 
陳 \\
張 \\
雑姓 \\
$\times$ \\
方 \\
\end{tabular} & \begin{tabular}{|l} 
陳公祠 \\
張公祠 \\
循良祠 \\
$\times$ \\
$\times$ \\
府前方氏宗祠 $\ominus$
\end{tabular} & \begin{tabular}{|l} 
祀典 \\
祀典 \\
祀典 \\
$\times$ \\
$\times$ \\
宮室
\end{tabular} & \begin{tabular}{|c|} 
祠 \\
祠 \\
祠 \\
$\times$ \\
$\times$ \\
宗祠
\end{tabular} \\
\hline & & 州学礼殿左 & 劉 & 30 & 知郡寺丞劉公生祠 & 祀典 & 生祠 & $\times$ & $\times$ & $\times$ & $\times$ \\
\hline & & 州学西偏 & 孫 & 31 & 郡守孫公生润 & 祀典 & 生润 & 孫 & 孫公䄇 & 祀典 & 祠 \\
\hline & 束北隅 & $\begin{array}{l}\text { 府学東 } \\
\text { 天寧寺左 } \\
\text { 府東門内 }\end{array}$ & $\begin{array}{l}\text { 愓 } \\
\text { 舒 }\end{array}$ & \begin{tabular}{|l|}
19 \\
17
\end{tabular} & $\begin{array}{l}\text { 楊先生祠 } \\
\text { 舒先生齐 }\end{array}$ & \begin{tabular}{|l|} 
祀典 \\
祀典
\end{tabular} & $\begin{array}{l}\text { 祠 } \\
\text { 部 }\end{array}$ & \begin{tabular}{|l} 
楊 \\
舒 \\
雑姓
\end{tabular} & $\begin{array}{l}\text { 楊先生祠 } \\
\text { 舒先生祠 } \\
\text { 何留一公词 }\end{array}$ & $\mid \begin{array}{l}\text { 祀典 } \\
\text { 祀典 } \\
\text { 部曲 }\end{array}$ & $\begin{array}{l}\text { 祠 } \\
\text { 祠 } \\
\text { 词 }\end{array}$ \\
\hline & & 府学左 & & & & & & 楊 & 楊宗伯祠 & 宮窒 & 裔 \\
\hline & & 斗山麓 & & & & & & 朱 & 朱氏宗祠 & 宮室 & 宗䄇 \\
\hline & 西北隅 & $\begin{array}{l}\text { 穆家巷左 } \\
\text { 東察院前 }\end{array}$ & & & & & & 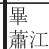 & \begin{tabular}{|l|} 
畢氏宗䙐 \\
蕭江統宗祠
\end{tabular} & \begin{tabular}{|l|l|} 
宮室 \\
室
\end{tabular} & $\begin{array}{l}\text { 宗祠 } \\
\text { 宗祠 }\end{array}$ \\
\hline & 鰙城中 & 朝水門郭外 & 蘭 & 5 & 罋将軍廟 & 祀典 & 廟 & 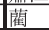 & 藺将軍廟 & 祀典 & 廟 \\
\hline \multirow{6}{*}{$\begin{array}{l}\text { 徽 } \\
\text { 州 } \\
\text { 府 } \\
\text { 城 } \\
\text { 外 }\end{array}$} & 東関 & \begin{tabular}{|l} 
隹城東 \\
紫陽門 \\
迎恩枋 \\
上路 \\
上路 \\
上路 \\
上路 \\
接官亭 \\
城河上 \\
荷花池 \\
東門 \\
龍舌頭 \\
桃源馾 \\
東関
\end{tabular} & 羅 & 40 & 慈恩 & 宮室 & 堂 & $\begin{array}{l}\text { 汪 } \\
\text { 史 } \\
\text { 雑姓 } \\
\text { 雑姓 } \\
\text { 李 } \\
\text { 程 } \\
\text { 汪 } \\
\text { 汪 } \\
\text { 汪 } \\
\text { 程 } \\
\text { 許 } \\
\text { 江 } \\
\text { 江 } \\
\times\end{array}$ & 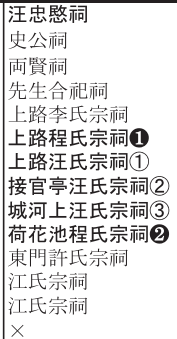 & \begin{tabular}{|c|} 
祀典 \\
祀典 \\
祀典 \\
祀典 \\
宮室 \\
宮室 \\
宮室 \\
宮室 \\
宮室 \\
宮室 \\
宮室 \\
宮室 \\
宮室 \\
$\times$ \\
$\times$
\end{tabular} & 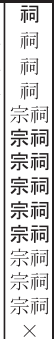 \\
\hline & \multirow[t]{3}{*}{ 西関 } & \multirow{3}{*}{$\begin{array}{l}\text { 城南龍井山 } \\
\text { 城南山麓下 } \\
\text { 城陽山 } \\
\text { 忠謢侯廟右 } \\
\text { 府城南 } \\
\text { 太平興国寺 } \\
\text { 漁梁壩下 } \\
\end{array}$} & \multirow[t]{2}{*}{$\begin{array}{l}\text { 汪 } \\
\text { 汪 } \\
\text { 章 } \\
\text { 孫 } \\
\text { 任 }\end{array}$} & \multirow[t]{2}{*}{\begin{tabular}{|c|}
4 \\
9 \\
7 \\
21 \\
14
\end{tabular}} & \multirow[t]{2}{*}{$\begin{array}{l}\text { 忠助八侯廟 } \\
\text { 忠護侯廟 } \\
\text { 孝女謿 } \\
\text { 郡守孫公祠 } \\
\text { 任公祠-1 }\end{array}$} & \multirow[t]{2}{*}{\begin{tabular}{|l|} 
祀典 \\
祀典 \\
祀典 \\
祀典 \\
祀典
\end{tabular}} & \multirow[t]{2}{*}{$\begin{array}{l}\text { 廟 } \\
\text { 朝 } \\
\text { 朝 } \\
\text { 祠 } \\
\text { 祠 }\end{array}$} & \begin{tabular}{|l} 
汪 \\
汪 \\
$\times$ \\
$\times$ 孫 \\
任 \\
\end{tabular} & $\begin{array}{l}\text { 忠助八侯廟 } \\
\text { 忠護侯廟 } \\
\times \\
\text { 孫公祠 } \\
\text { 任公部 } \\
\end{array}$ & \begin{tabular}{|c|} 
祀典 \\
祀典 \\
$\times$ \\
$\times$ \\
祀典 \\
祀典 \\
\end{tabular} & $\begin{array}{l}\text { 廟 } \\
\text { 廟 } \\
\times \\
\text { 祠 } \\
\text { 祠 } \\
\end{array}$ \\
\hline & & & & & & & & 呂 & 呂侍郎祠 & 宮室 & 祠 \\
\hline & & & & 43 & 陸氏祠堂 & 宮室 & 祠堂 & 陸 & 陸氏宗祠 & 宮室 & 宗䄇 \\
\hline & 北関 & 北関門外 & & & & & & 詹 & 詹氏宗祠 & 宮室 & 宗祠 \\
\hline & 古関 & $\begin{array}{l}\text { 古城関 } \\
\text { 古城関 } \\
\text { 葛塘 }\end{array}$ & $\begin{array}{l}\text { 程 } \\
\text { 程 }\end{array}$ & $\begin{array}{l}20 \\
32\end{array}$ & \begin{tabular}{|l} 
程都憲祠 \\
程元成墳寺
\end{tabular} & \begin{tabular}{|l|} 
祀典 \\
寺観
\end{tabular} & \begin{tabular}{|l|l} 
祠 \\
墳寺 \\
\end{tabular} & $\begin{array}{l}\times \\
\text { 程 } \\
\text { 只 }\end{array}$ & $\begin{array}{l}\times \\
\text { 程元鳳墳寺(積慶寺) } \\
\text { 葛塘吳氏宗祠 }\end{array}$ & $\begin{array}{c}\times \\
\text { 寺観 } \\
\text { 宮室 }\end{array}$ & $\begin{array}{c}\times \\
\text { 墳寺 } \\
\text { 宗祠 }\end{array}$ \\
\hline & 都 & 新館 & 汪 & 23 & 忠烈行 & 祀典 & 行祠 & 汪 & 忠烈行祠(1) & 祀典 & 行祠 \\
\hline $\begin{array}{l}\text { 明 } \\
\text { 徳 }\end{array}$ & & $\begin{array}{l}\text { 方塘 } \\
\text { 竦口 }\end{array}$ & & & & & & $\begin{array}{l}\text { 胡 } \\
\text { 程 }\end{array}$ & \begin{tabular}{|l} 
方塘胡氏宗祠 \\
竦口程氏宗祠3
\end{tabular} & \begin{tabular}{|l|l|} 
宮室 \\
宮室
\end{tabular} & $\begin{array}{l}\text { 宗祠 } \\
\text { 宗祠 }\end{array}$ \\
\hline 郷 & 三都 & 竦口 & & & & & & 注 & & 宮室 & 宗祠 \\
\hline & & 豊堨 & & & & & & 汪 & 豊堨汪氏宗祠 (5) & 宮室 & 宗泀 \\
\hline 登 & 一都 & \begin{tabular}{|l} 
藤源(仏川) \\
項里
\end{tabular} & 唐 & 38 & 孝思堂 & 宮室 & 堂 & $\begin{array}{l}x \\
\text { 殷 } \\
\end{array}$ & & $\begin{array}{c}\times \\
\text { 宮室 } \\
\end{array}$ & $\begin{array}{c}\times \\
\times \\
\text { 宗祠 }\end{array}$ \\
\hline 郷 & 七都 & 桂林 & & & & & & 洪 & 桂林洪氏宗祠 & 宮室 & 宗祠 \\
\hline
\end{tabular}

を基にし、(図4) 注 ${ }^{23}$ のように、徽州府城を中心として城内に「東南・ 西南・東北・西北隅」(18 件)、城外には「東関(欴県城) ・西関・北関 ・ 古関」(25 件)があり、また、農村部には、後掲(図5)のように、明徳郷、 登瀛郷など 16 郷の下に 37 都 (75 件、場所不明 3 件)が敷かれている。(表 5)のように、城内・城外には数多くの祠堂建築が見られ、その他、 農村部の中鵠郷 (十九都)、衮繡郷 (二十二、二十三都) などにも多くの祠 堂建築が残されている。次に、どのような要因により形成されたか、 さらに、商業活動、宗族村落などとの関連性を検討してみたい。

なお、明代の朝廷の礼制改革に伴って、嘉靖府志」の宮室篇では、 宗祠とするのが一般的であり、「弘治府志」の陸氏、呉氏の祠堂(綱掛) は宗祠に変更され、新たに現れた宗祠も数多くある。その他、楊宗 伯祠 (東北隅・府学左)、呂侍郎祠 (西関・太平興国寺)、鮑提幹祠 (二十三都・

\begin{tabular}{|c|c|c|c|c|c|c|c|c|c|c|c|}
\hline \multirow{3}{*}{$\begin{array}{l}\text { 徳 } \\
\text { 政 } \\
\text { 郷 }\end{array}$} & 八都 & \begin{tabular}{|l|} 
雲嵐山山 \\
雲霧塘
\end{tabular} & 汪 & & 越国公墓祠 & 兵墓 & 墓祠 & 汪 & \begin{tabular}{|l|} 
越国公墓祠 \\
需楁塘王氏宗祠
\end{tabular} & $\begin{array}{l}\text { 兵墓 } \\
\text { 室 }\end{array}$ & \begin{tabular}{|l|} 
菱祠 \\
祠
\end{tabular} \\
\hline & 九都 & \begin{tabular}{|l} 
黄村 \\
徐村 \\
徐村 \\
沙溪 \\
沙溪
\end{tabular} & & & & & & $\begin{array}{l}\text { 黄 } \\
\text { 徐 } \\
\text { 徐 } \\
\text { 汪 } \\
\text { 倰 }\end{array}$ & 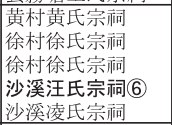 & $\begin{array}{l}\text { 宮室 } \\
\text { 宮室 } \\
\text { 宮室 } \\
\text { 宮室 } \\
\text { 宮室 }\end{array}$ & 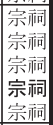 \\
\hline & +都 & 飛布山 & 雑姓 & 3 & 飛布廟 & 祀典 & 廟 & 雑 & 飛布廟 & 祀典 & 廟 \\
\hline $\begin{array}{l}\text { 寧 } \\
\text { 泰 } \\
\text { 郷 }\end{array}$ & 十二都 & \begin{tabular}{|l|} 
任公村 \\
崇福寺
\end{tabular} & 䚾 & \begin{tabular}{l|}
16 \\
34
\end{tabular} & $\begin{array}{l}\text { 任公祠-2 } \\
\text { 金氏夫人墓祠 } \\
\text { (汪氏墓阿) }\end{array}$ & \begin{tabular}{|l|} 
祀典 \\
寺観
\end{tabular} & \begin{tabular}{|l|} 
呞 \\
墓柌 \\
\end{tabular} & $\begin{array}{l}\text { 任 } \\
\times\end{array}$ & $\begin{array}{l}\text { 任公祠 }-2 \\
\times\end{array}$ & $\begin{array}{l}\text { 祀典 } \\
\times\end{array}$ & $\begin{array}{l}\text { 蓪 } \\
\times\end{array}$ \\
\hline $\begin{array}{l}\text { 通 } \\
\text { 德 } \\
\text { 郷 }\end{array}$ & 十四都 & \begin{tabular}{|l|} 
通徳郷龍山 \\
通徳郷容成 \\
呈坎
\end{tabular} & $\begin{array}{l}\text { 汪 } \\
\text { 汪 }\end{array}$ & \begin{tabular}{l|}
24 \\
25
\end{tabular} & $\begin{array}{l}\text { 忠烈行 } \\
\text { 忠烈行 }\end{array}$ & \begin{tabular}{|l|} 
祀典 \\
祀典
\end{tabular} & \begin{tabular}{|l|l|} 
行祠 \\
行祠
\end{tabular} & \begin{tabular}{|l} 
汪 \\
汪 \\
羅
\end{tabular} & \begin{tabular}{|l} 
忠烈行祠(2) \\
烈行祠(3) \\
呈坎羅氏宗祠
\end{tabular} & $\begin{array}{l}\text { 祀典 } \\
\text { 祀典 } \\
\text { 宮室 }\end{array}$ & \begin{tabular}{|l|} 
行祠 \\
行祠 \\
宗祠
\end{tabular} \\
\hline \multirow{5}{*}{$\begin{array}{l}\text { 孝 } \\
\text { 悌 } \\
\text { 郷 }\end{array}$} & \multirow{3}{*}{ 十五都 } & \multirow{3}{*}{$\begin{array}{l}\text { 陳村山上 } \\
\text { 澄墙 } \\
\text { 潜川曹門 } \\
\text { 潜川楼下 }\end{array}$} & 章 & 6 & 大姑小姑廟 & 祀典 & 廟 & 章 & 大姑小姑廟 & 祀典 & 廟 \\
\hline & & & 呉 & 42 & 呉氏祠堂 & 宮室 & 嗵堂 & 與 & 澄塘呉氏宗茼 & 宮室 & \\
\hline & & & & & & & & $\begin{array}{l}\text { 汪 } \\
\text { 汪 }\end{array}$ & \begin{tabular}{|l} 
潜川汪氏宗祠 (7) \\
潜川汪氏宗祠88
\end{tabular} & \begin{tabular}{|l|} 
宮室 \\
室室
\end{tabular} & \begin{tabular}{|l|} 
宗祠 \\
宗祠
\end{tabular} \\
\hline & 二十都 & \begin{tabular}{|l} 
信行 \\
信行 \\
汪川
\end{tabular} & $\begin{array}{l}\text { 汪 } \\
\text { 汪 } \\
\text { 謝 }\end{array}$ & \begin{tabular}{|l|}
26 \\
18 \\
22
\end{tabular} & $\begin{array}{l}\text { 忠烈行祠-4 } \\
\text { 介庵先生祠 } \\
\text { 諌議祠 }\end{array}$ & \begin{tabular}{|l|} 
祀典 \\
祀典 \\
祀典
\end{tabular} & \begin{tabular}{|c|} 
行祠 \\
祠 \\
祠 \\
\end{tabular} & $\begin{array}{l}\text { 汪 } \\
\text { 汪 } \\
\text { 謝 }\end{array}$ & $\begin{array}{l}\text { 忠烈行祠(4) } \\
\text { 介庵先生祠 } \\
\text { 諫議祠 }\end{array}$ & $\begin{array}{l}\text { 祀典 } \\
\text { 祀典 } \\
\text { 祀典. }\end{array}$ & $\begin{array}{c}\text { 行祠 } \\
\text { 祠 } \\
\text { 祠 }\end{array}$ \\
\hline & & 聯墅 & 方 & 36 & 如存 & 宮室 & 庵 & $\frac{1}{x}$ & $x$ & $\times$ & \\
\hline \multirow{4}{*}{$\begin{array}{l}\text { 中 } \\
\text { 鵠 } \\
\text { 郷 }\end{array}$} & 十六都 & \begin{tabular}{|l|} 
臨河 \\
西溪南
\end{tabular} & & & & & & 程 & \begin{tabular}{|l|} 
世忠行祠2 \\
西溪南呉氏宗祠 \\
\end{tabular} & $\begin{array}{l}\text { 祀典 } \\
\text { 宮室 }\end{array}$ & \begin{tabular}{|l|} 
\\
行祠 \\
宗祠
\end{tabular} \\
\hline & 十七都 & \begin{tabular}{|l} 
石橋 \\
橦塘
\end{tabular} & & & & & & 黉 & $\begin{array}{l}\begin{array}{l}\text { 石橋呉氏宗祠 } \\
\text { 竦塘黄氏宗祠 }\end{array} \\
\end{array}$ & 宮室 & \begin{tabular}{|l} 
宗福 \\
宗福
\end{tabular} \\
\hline & 十八都 & $\begin{array}{l}\text { 托山 } \\
\text { 托山 } \\
\text { 托山 }\end{array}$ & & & & & & $\begin{array}{l}\text { 程 } \\
\text { 程 } \\
\text { 程 }\end{array}$ & $\begin{array}{l}\text { 世忠行祠 3 } \\
\text { 托山程氏宗祠4 } \\
\text { 托山程氏宗祠 }\end{array}$ & \begin{tabular}{|l} 
祀典 \\
宮室 \\
宮室
\end{tabular} & $\begin{array}{l}\text { 行峒 } \\
\text { 宗峒 } \\
\text { 宗泀 }\end{array}$ \\
\hline & 十九都 & $\begin{array}{l}\text { 岩鎮 } \\
\text { 岩鎮 } \\
\text { 岩鎮 } \\
\text { 岩鎮 } \\
\text { 梅村 } \\
\end{array}$ & & & & & & $\begin{array}{l}\text { 棌 } \\
\text { 鄭 } \\
\text { 余 } \\
\text { 院 } \\
\text { 葉 }\end{array}$ & 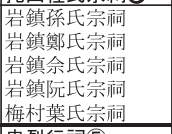 & \begin{tabular}{|l|} 
宮室 \\
宮室 \\
宮室 \\
宮室 \\
\end{tabular} & 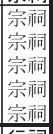 \\
\hline \multirow{8}{*}{$\begin{array}{l}\text { 依 } \\
\text { 紼 } \\
\text { 郷 }\end{array}$} & & 棠棧龍山 & 汪 & 27 & 忠烈行祠-5 & 祀典 & 行祠 & 汪 & 忠烈行祠(5) & 祀典 & 行祮 \\
\hline & & & 程 & 29 & 世忠 & 祀典 & 行祠 & $\begin{array}{l}\text { 程 } \\
\text { 程 }\end{array}$ & \begin{tabular}{|l|} 
世忠行祠 19 \\
槐塘程氏宗祠 6
\end{tabular} & \begin{tabular}{|l} 
祀典 \\
宮室
\end{tabular} & \\
\hline & & 棠棧 & & & & & & 鮑 & 棠樾鮑氏宗祠 & 宮室 & 宗祠 \\
\hline & & 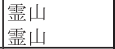 & 方 & 37 & 報徳庵 & 宮室 & 庵 & $\begin{array}{l}x \\
\text { 方 }\end{array}$ & \begin{tabular}{|l}
$\times$ \\
霊山方氏宗祠 $\ominus$
\end{tabular} & \begin{tabular}{|l}
$\times$ \\
宮室
\end{tabular} & $\begin{array}{c}\times \\
\text { 宗祠 } \\
\end{array}$ \\
\hline & \multirow[b]{4}{*}{ 二十三都 } & 鄭村双橋北 & 鄭 & 12 & 令君廟 & 祀典 & 廟 & 鄭 & 令君㾰 & 泉圭典 & 廟 \\
\hline & & & & & & & & 陳 & $\begin{array}{l}\text { 明陳太守祖母 } \\
\text { 郭夫人墓祠 }\end{array}$ & 丘墓 & 墓祠 \\
\hline & & 向杲 & & & & & & 鮑 & 鮑提幹䄇 & 宮室 & 䄇 \\
\hline & & $\begin{array}{l}\text { 向杲 } \\
\text { 潭渡 } \\
\text { 潭渡 } \\
\text { 仇村 } \\
\text { 下市 } \\
\end{array}$ & & & & & & \begin{tabular}{|l} 
呉 \\
黄 \\
黄 \\
黄 \\
黄
\end{tabular} & \begin{tabular}{|l|} 
向杲呉氏宗祠 \\
㴗渡黄氏宗祠 \\
潭渡黄氏宗祠 \\
仇村黄氏宗祠 \\
下市黄氏宗祠 \\
\end{tabular} & \begin{tabular}{|l|} 
宮室 \\
宮窒 \\
宮室 \\
宮室 \\
\end{tabular} & 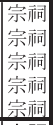 \\
\hline \multirow{4}{*}{$\begin{array}{l}\text { 永 } \\
\text { 豊 } \\
\text { 郷 }\end{array}$} & & 石岡 & & & & & & 汪 & 石岡汪氏宗祠(9) & 宮室 & 宗嚆 \\
\hline & 二十四都 & & & & & & & 汪 & & 宮室 & 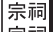 \\
\hline & & & & & & & & \begin{tabular}{|l} 
方 \\
方
\end{tabular} & & $\begin{array}{l}\text { 宮室 } \\
\text { 宮寚 }\end{array}$ & \begin{tabular}{|l} 
宗稿 \\
宗峒
\end{tabular} \\
\hline & 二十八都 & \begin{tabular}{|l|} 
洪源坑口 \\
洪源竹林里
\end{tabular} & & & & & & $\begin{array}{l}\text { 洪 } \\
\text { 洪 }\end{array}$ & \begin{tabular}{|l|} 
洪源洪氏世祠 \\
洪源洪氏宗柌
\end{tabular} & 宮室 & \begin{tabular}{|l|l|} 
宗祠 \\
宗棃
\end{tabular} \\
\hline $\begin{array}{l}\text { 侣 } \\
\text { 愛 } \\
\text { 郷 }\end{array}$ & 二十五都 & $\begin{array}{l}\text { 筸墩 } \\
\text { 南溪南 } \\
\text { 南溪南 }\end{array}$ & 程 & 8 & 世忠廟 & 祀典 & 廟 & \begin{tabular}{|l} 
程 \\
江 \\
娯
\end{tabular} & \begin{tabular}{|l|} 
世忠廟 \\
南溪南江氏宗洞 \\
南溪南呉氏宗祠
\end{tabular} & \begin{tabular}{|l} 
祀典 \\
宮室 \\
宮室
\end{tabular} & $\begin{array}{c}\text { 廟 } \\
\text { 宗祠 } \\
\text { 宗棃 }\end{array}$ \\
\hline $\begin{array}{l}\text { 長 } \\
\text { 寿 } \\
\text { 郷 }\end{array}$ & 二十七都 & $\begin{array}{l}\text { 龍閣山 } \\
\text { 浯孫 }\end{array}$ & 汪 & 28 & 忠烈行祠-6 & 祀典 & 行祠 & \begin{tabular}{|l} 
汪 \\
朱
\end{tabular} & \begin{tabular}{|l} 
忠烈行祠6 \\
浯孫朱氏宗祠
\end{tabular} & \begin{tabular}{|l} 
祀典 \\
宮室
\end{tabular} & \begin{tabular}{|l} 
行祠 \\
宗祠
\end{tabular} \\
\hline $\begin{array}{l}\text { 寧 } \\
\text { 仁 } \\
\text { 郷 }\end{array}$ & 三十七都 & 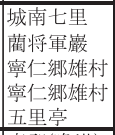 & \begin{tabular}{|l} 
汪 \\
藺 \\
鮑
\end{tabular} & \begin{tabular}{|l}
11 \\
15 \\
33
\end{tabular} & & \begin{tabular}{|l|} 
祀典 \\
祀典 \\
寺観
\end{tabular} & \begin{tabular}{|l|} 
廟 \\
祠 \\
墳庵
\end{tabular} & \begin{tabular}{|l} 
汪 \\
藺 \\
鮑 \\
曹 \\
程
\end{tabular} & \begin{tabular}{|l|} 
福恵廟 \\
藺将軍祠 \\
鮑氏墳庵(南極観) \\
雄村曹氏宗祠 \\
五里亭程氏宗祠 8 \\
\end{tabular} & \begin{tabular}{|l|} 
祀典 \\
祀典 \\
寺観 \\
宮室 \\
宮室
\end{tabular} & \begin{tabular}{|c|} 
廟 \\
祠 \\
墳庵 \\
宗祠 \\
宗祠 \\
\end{tabular} \\
\hline \multirow{2}{*}{$\begin{array}{l}\text { 孝 } \\
\text { 女㚹 } \\
\end{array}$} & 三十五都 & $\begin{array}{l}\text { 章郝(瞻淇) } \\
\text { 大阜 }\end{array}$ & & & & & & 汪 & \begin{tabular}{|l|} 
章祁汪氏宗祠(11) \\
潘氏宗祠
\end{tabular} & 宮室 & \begin{tabular}{|l|} 
宗祠 \\
宗祠
\end{tabular} \\
\hline & 三十六都 & 淪潭 & & & & & & 方 & 淪潭方氏宗䄇国 & 宮室 & 宗峒 \\
\hline 上長 & 三十三都 & 柳亭山麓左 & 方 & 1 & \begin{tabular}{|l} 
方儲廟 \\
(真応廟·仙翁
\end{tabular} & 祀典 & 廟 & 方 & \begin{tabular}{|l|} 
方儲廟 \\
(真応廟·仙翁廟)
\end{tabular} & 祀典 & \begin{tabular}{|l|l} 
廟 \\
\end{tabular} \\
\hline $\begin{array}{l}\text { 不 } \\
\text { 明 }\end{array}$ & - & $\begin{array}{l}\text { 乳溪(汝溪) } \\
- \\
-\end{array}$ & 銭 & $\begin{array}{l}10 \\
39\end{array}$ & \begin{tabular}{|l} 
英烈廟 \\
孝思堂
\end{tabular} & 祀典 & $\begin{array}{l}\text { 廟 } \\
\text { 堂 }\end{array}$ & 銭 & $\begin{array}{l}\text { 英烈廟 } \\
\times \\
\text { 孫氏慕源 }\end{array}$ & \begin{tabular}{|c|} 
祀典 \\
$\times$ \\
宮室
\end{tabular} & \begin{tabular}{|c|c|} 
廟 \\
$\times$
\end{tabular} \\
\hline
\end{tabular}


向杲)のように宮室篇に記された祠は、宗族中の一人の有名な祖先 (楊宗伯・呂侍郎・鮑提幹)を祀る祠から宗祠へ変化しており、祭祀者 が宗族内部に限られた点で祀典篇の祠 (祠廟) と区別できる。

\section{$5-2$. 祠堂建築の分布図}

欴県は、徽州地区の商業の中心として周辺の練江、浙江、豊楽水 の河川を新安江に集める豊かな水系を結び、水上交通綱を発達させ てきた。地形は、県の東部・南部・東北部が山間地であり、西部・ 北部が平坦地である。㪘県の祠堂建築の分布は、前掲の歴代地方志 に記されている地名・村落名と比定し、それらを地図上に記すと、(図 5 ) のようになる。また、前掲の (表 5 ) の祠堂建築を祠廟(廟、祠、行 祠、生祠) - 墓祠 (墳庵、墳寺、墓祠) - 宗祠 (庵、堂、祠堂、宗祠)に分類 し、地域別に集計すると、(表 6 ) のようになる。

「弘治府志」の 43 例 [ 一印] は、城内に 8 例 (祠廟 7+宗祠 1)、城外に 9 例(祠廟 $6+$ 墓祠 $1+$ 宗祠 2)があり、全体の四割を占める。この他、 農村部の 24 例 (部廟 $17+$ 墓部 $3+$ 宗祠 4) は、城の西方の平坦地 (十四 · 十五・二十・二十二都など)に分布している。

「嘉靖府志」の 110 例 [ロ印]は、「弘治府志」の 43 例と比べ、総数が 2.6 倍に増加し、分布が西・南方へ移行している。この中で、地方 信仰の祠廟は城内・城外・農村部では 1. 1 1. 4 倍と大きな変化が無 い。しかし、祖先祭祀においては、墓祠は数が変らないものの、宗 祠は城内が 5 倍、城外が 6.5 倍と増加し、特に、農村部では 12.3 倍に増加している。このように、明代中期以降、祠堂建築は宗祠の 建設が主流となったことが分る注 24)。(図 5 ) (表 6)

\section{5-3. 商業活動と祠堂建築の分布}

(図 5 ) の中で注目すべきは、祠堂建築が川である水上交通路に沿 って広がっていることである。「嘉靖府志」第二巻*風俗篇によると、
地方信仰において「正月七日の夕、紫姑神を迎い；二月二十八日、 欴県と休寧県では忠烈廟から越国公汪華像の巡行や供宴を行い; 三 月三日、数多く祠廟の集まる河西(西関)で船競、執蘭招魂祭を行い 云々」とあり、廟祝や廟会活動が行われている。廟祝や廟会による 定期的な祭祀活動は、周辺地域の人々を集めて祭祀を行い、交易場 として商品の交換や販売を行うなど、商人たちの重要な販路となっ ていた。このように商人の活動、人々の祭祀は、当時の主な交通手 段であった水上交通路にそって祠廟への信仰を拡げ、本廟から分れ て行祠を設ける契機になったと考えられる。

一方、徽州の人々の生業は主に商業であり、宗族村落も交通便利 な水路周辺に拡大して行くことになる。祖先祭祀において明代嘉靖 年間の礼制改革に従い、徽州商人は商売により富を築くと、宗族村 落の中に宗祠の建設を積極的に行った。このような背景により、数 多くの祠堂建築が水路周辺に数多く分布することとなった。

\section{$5-4$. 宗族村落の発展と祠堂建築の分布}

祠堂建築において、祠廟・墓祠・宗祠がいずれも掲載されるのは、 明代の弘治・嘉靖両志であり、宗族村落の統計を記すのは、明代の 嘉靖府志とその以降の地方志であるため、両者の数が共に掲載され る「嘉靖府志」より地域別に抽出すると、(表 5 ・附表)のようになり、 宗族村落の増加に応じて、祠堂建築が増えていることが分る。さら に、清代の地方志には宗祠が記載されてないが、宗族村落の状況よ り推定されるため、「道光県志」の数を取り上げると、宗族村落の数 が明代に比べ大幅に増しており、宗祠の大幅な増加が予測される。

なお、(表 5 ・附表)の綱掛の部分について見ると、明代嘉靖年間 には、祠堂建築が数多くあった城内、城外、三都、九都などの地域 では、その後、宗族村落の発展が衰え、2〜 倍の増加に止まってい

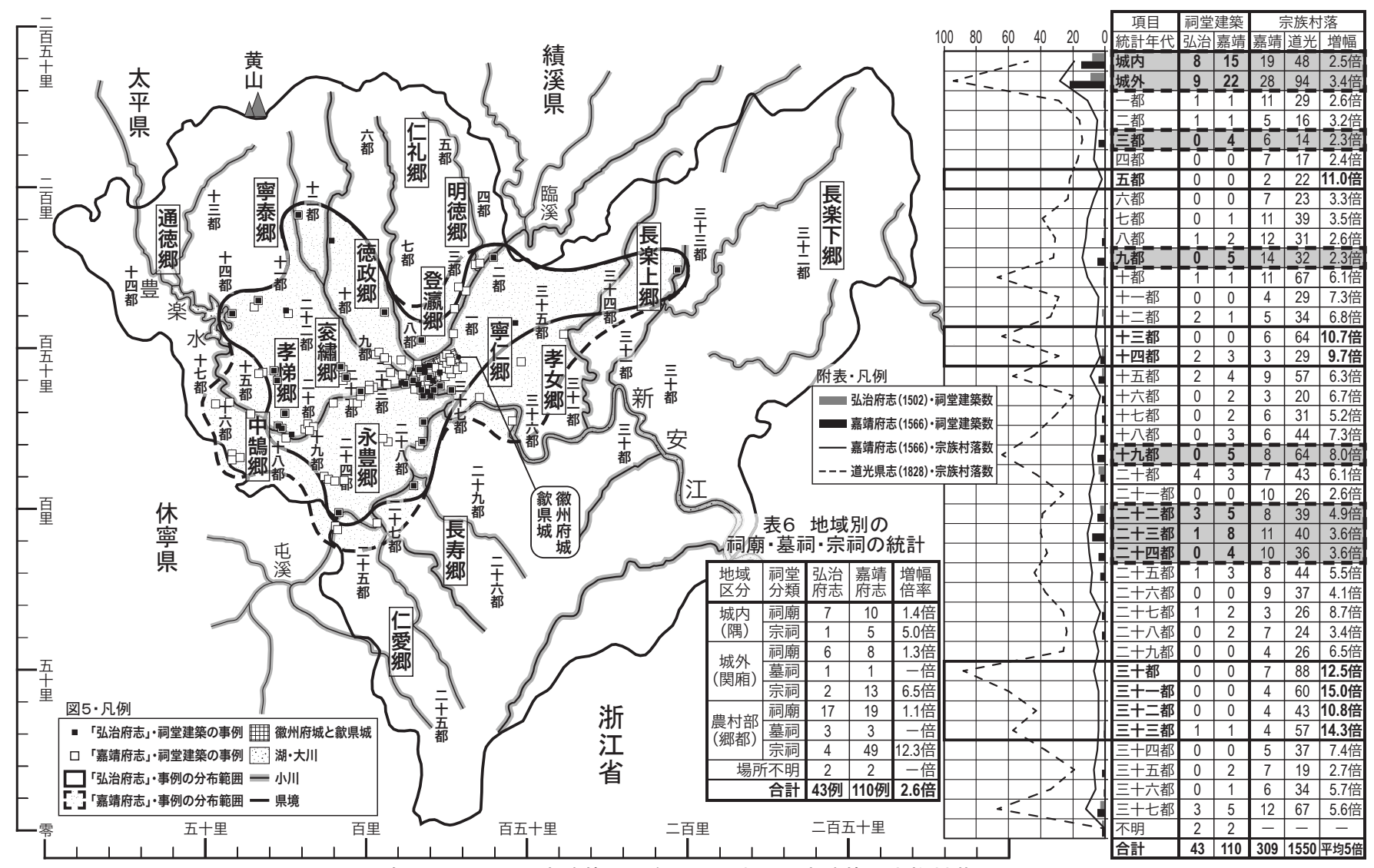

図 5 㰸県・明代の祠堂建築の分布図（附表 祠堂建築と宗族村落の関係） 
る(十九都を除く)。それに対し、黒枠で囲まれ、徽州府城より遠い山 岳地帯 (北方向の五都、西北方向の十三都 $\cdot$ 十四都、東北方向の三十都 三 十三都)の村落では 9.7 倍から 15.0 倍にまで増え、これらの地域の 祠堂建築が急激に増加したことが予測される

\section{5-5. 宗族の組織化と祠堂建築の分布}

宗族の形成・組織化が地域に浸透したことにより、地方信仰と祖 先祭祀との関係がどのように変化したか、前掲(表 5 ) による明代弘 治・嘉靖年間の祠堂建築 (祠廟・墓祠・宗祠)について宗族別 (氏別)の 統計を取ると、(表 7$)^{\text {注 } 25)}$ のようになる。早期に徽州へ移住した汪・ 程・方氏は、他の宗族より祠堂建築が数多く記され、弘治年間には 祠廟(汪 11+程 3+方 1)が多数であり、嘉靖年間に入ると、祠廟(汪 $12+$ 程 4+方1)に大きな増加がなく、それに対し、宗祠 (汪 11+程 7+方 5) が 大幅に増えた。その他、複数姓を合祀寸る祠廟が増え、唄・黄氏な どでは宗祠が大幅に増加した。このように、嘉靖年間以降、地方信 仰はそれ以前に比べて衰退したのに対し、祖先祭祀は宗法思想の浸 透と社会的な活動の影響を受け、宗祠化に向かったと考えられる。

次に、地方信仰の祠廟から祖先祭祀の宗祠へと進展した汪・程・ 方氏の事例を取り上げて検討する。ここでは、汪・程・方氏の祠堂 建築は廟、行祠、墓祠、庵、宗祠などに分れるので、眓例によって 表示すると、(図6、図7、図 8)のようになる。この中には、行祠 と宗祠が複数あるので、前掲(表 5 ) のゴシック体の事例に対応させ、 汪氏は忠烈行祠 (1)～(6)、宗祠 (1)～(11)、程氏は世忠行祠 1 〜 3、宗祠

(1) - 万、方氏は宗祠 $\ominus$ 国のような番号を付して区別する。

(1) 汪氏は、(図 6 ) のように、徽州府城内の忠烈廟(唐 651)を起点と し、雲嵐山の越国公墓(唐 651) と越国公墓祠 (宋 1277) を加え、越国公・ 汪華の祭祀を主とする信仰圈の中心を形成した。その他、汪華の子 を祀る祠廟である忠助八侯廟(宋 1140)、忠護侯廟(宋 1176-89)、福恵 廟 (宋代) も忠烈廟の周辺に分布している。宋代以降、汪華の信仰は 忠烈廟として拡大し、忠烈廟から分立した忠烈行祠が川に沿って城 外の東北・西 - 南方向へ広がっていた。明代に入ると、榛県の城内 外・農村部の汪氏村落には宗祠が建てられ、忠烈廟、忠烈行祠の外 周に散在している。

（2）程氏は、（図 7 ) のように、本山である世忠廟(穼 1175-84)をみる と、程霊洗の旧宅と墓所のあった休寧県と䣄県が接する筀墩に建設 された。族譜を纏めた『新安名族志』前巻*程 ${ }^{17)}$ によると、筀墩は 徽州へ移住した程氏の始遷地であり、徽州・程氏の本家として代々 続き、時代を下って、筀墩から分家した程氏の宗族は徽州各地で新 たな村落を造った。また、䣄県では筀墩近くの槐塘、臨河、托山な どの程氏村落に世忠行祠や宗祠が次第に建てられ、城内に近い荷花 池、上路、五里亭、遠い竦口には宗祠が建てられた。

（3）方氏は、（図 8)のように、始祖の方儲が修行場とした柳亭山に 方儲廟 (漢代)が築かれたので、近くの霞坑、対溪などに方氏村落が 集まっている。宋代以降、方儲廟が宗祠化し、その周辺の方氏村落 には方儲と始祖を共同で祀る宗祠が建てられ、その他、霊山、聯墅、 羅田などにも祖先祭祀の庵や宗祠が次第に建てられた。

以上のように、汪氏は、地方神の汪華の祭祀を中心として「忠烈廟」 (本廟)から「忠烈行祠」へと分化し、地方信仰圈が拡張され、城内外、 農村部の汪氏村落では宗祠の建設が行われた。一方、程氏は、程氏 村落の発展と共に「世忠廟」(本廟)から「世忠行祠」へと分化し、宗祠の 建設が行われ、方氏の場合は山間地に方儲廟が築かれたため、各地
に方氏村落が分散し、そこでも宗祠が建てられた。

表 7 宗族別の祠堂建築の統計 (弘治府志: 43 例 嘉靖府志: 110 例)

\begin{tabular}{|c|c|c|c|c|c|c|c|c|c|c|c|c|c|c|c|c|c|c|c|}
\hline 往 & & & & & & & & & & & & & & 唐 & & & & $\begin{array}{l}\text { 晋唐代 } \\
\text { 隋五完 }\end{array}$ & 総 \\
\hline 㫊 & 汪程 & 程方 & 孫 & 鄭 & & 章 & $\begin{array}{l}\text { 銭 } \\
\text { 舒 } \\
\text { 謝 }\end{array}$ & 李 & & 逕 & 江 & & 唐 & 陳 & & & & $\begin{array}{l}\text { 畢胡会 } \\
\text { な殷阮 } \\
\text { ど主葉 } \\
\text { 凌潘 }\end{array}$ & 笠 \\
\hline & \begin{tabular}{|l|l}
11 & 3 \\
\end{tabular} & $\begin{array}{lll}3 & 1 \\
\end{array}$ & 2 & $1 \times 2$ & $\begin{array}{ll}2 \times 2 \\
2\end{array}$ & \begin{tabular}{l|l}
2 & 1
\end{tabular} & $1 \times 3$ & & $1-$ & . & - & & - & - & - & & - & - & 31 \\
\hline & \begin{tabular}{|l|l|l|} 
& 1
\end{tabular} & 1 & - & - & -- & - & - & - & 1 & - & - & & - & - & - & - & - & - & 4 \\
\hline & -- & -2 & - & - & -- & - & - & - & -- & 1 & 1 & & $\begin{array}{l}2 \\
2\end{array}$ & - & - & -1 & - & - & 8 \\
\hline & \begin{tabular}{|l|l|l|}
13 & 4 \\
\end{tabular} & $\begin{array}{lll}4 & 3 \\
\end{array}$ & 2 & 2 & 42 & \begin{tabular}{l|l}
2 & 1
\end{tabular} & 3 & 1 & 1 1 & 1 & 1 & & 1 & - & - & - & - & - & 43 \\
\hline & \begin{tabular}{|l|l|}
12 & 4
\end{tabular} & \begin{tabular}{l|l}
4 & 1 \\
\end{tabular} & 2 & $1 \times 2$ & $2 \times 2$ & 15 & $1 \times 3$ & - & - & - & - & & - & 1 & $1 \times 3$ & -1 & - & - & 38 \\
\hline & \begin{tabular}{|l|l}
1 & 1 \\
\end{tabular} & 1 & - & - & - & -1 & - & - & -1 & - & - & & - & 1 & - & -1 & - & - & 4 \\
\hline & \begin{tabular}{|l|l}
11 & 7 \\
\end{tabular} & \begin{tabular}{l|l}
7 & 5
\end{tabular} & 2 & $1 \times 2$ & - & - & - & 1 & 2 & 6 & 3 & & $2-$ & - & -6 & \begin{tabular}{l|l}
6 & 3
\end{tabular} & 2 & $1 \times 14$ & 68 \\
\hline & \begin{tabular}{|l|l|}
24 & 1 \\
\end{tabular} & & 4 & 4 & $\begin{array}{lll}4 & 1\end{array}$ & 15 & 3 & 1 & -3 & & $3 \mid$ & & - & 2 & 3 & & & 14 & 110 \\
\hline
\end{tabular}
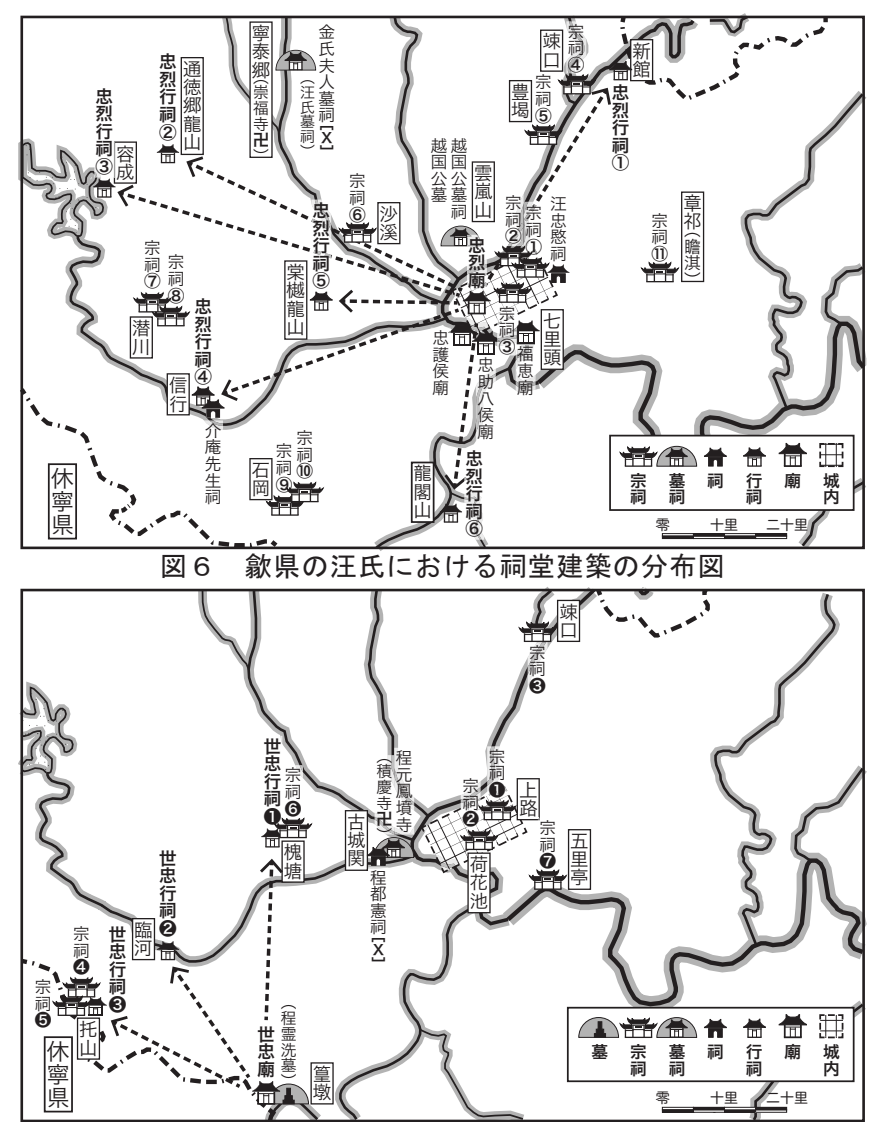

図 7 顽県の程氏における祠堂建築の分布図

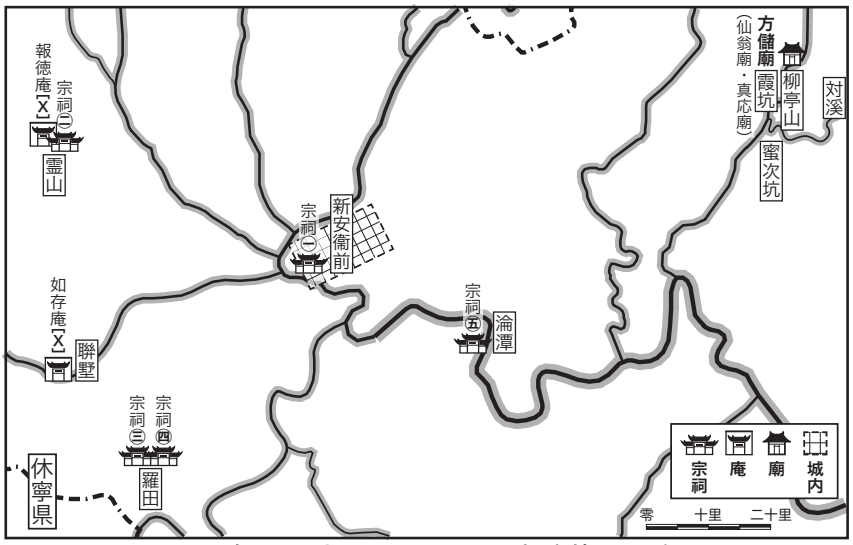

図 8 㰸県の方氏における祠堂建築の分布図

[X]印:「弘治府志」にあり、「嘉靖府志」には無くなった事例である。 
6. 宗祠の分化・発展について

前掲の (図 5 ・附表)によると、清代以降、山岳地帯の五都、十三 都、十四都、三十都〜三十三都の村落の増加は、人口密度の低い山 岳地域への転居がその要因と考えられる。そこで、文献史料ならび に祠堂遺構が多く残されている三十二都の洪氏一族について、宗族 村落の発展と祠堂建設との関係を検討してみたい。

歎県の洪氏一族の移住については、前掲の『新安名族志』後巻* 洪 ${ }^{17)}$ による洪氏村落の記載、ならびに黄山市文物局から収集した洪 氏祠堂の遺構史料 ${ }^{12)}$ を加えて本家と分家の関係を整理すると、（図 9 )のようになる。さらに、前掲の地方志により (表 9 ・附表)を作成 し、歌県・三十二都にある村落数を取り上げると、これら洪氏村落 の形成過程が窺える。

洪氏は、下図中央の「葉村」に唐代から定住し始め、一族が同居し て八世になると、西隣の「中村」に分家し、その次は、「慈坑」(13 世分 家)、「老竹林」(17 世分家)、「三陽坑」(19 世分家)などに洪氏村落を造 った。そのため、最初の定住地(葉村)に建てた始祖を祀る叙倫堂は、 洪氏一族にとっての主宰と認められ、「統宗祠」と呼ばれた。中村、 慈坑、老竹林などは他の定住地に建てられ、各村落の始遷祖を祀る 祠堂は「宗祠」と呼ばれ、統宗祠と同様に叙倫堂という堂号注 ${ }^{26)}$ が用 いられた。各村落では、何世代も経て人口が増えると、宗族から派 生した支派の祖先を祀る祠堂が建てられた。例えば、葉村の敬本堂、 中村の世徳堂、太古堂、啓徳堂、老竹林の存古堂、致遠堂、中和堂、 三陽坑の孝友堂、本立堂、仁本堂などがあり、共に「支祠」と言われ
た。なお、湌県では『家礼』に示される「家祠」もあったが、洪氏村

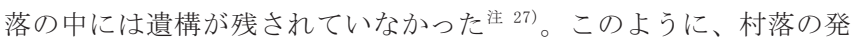
展と共に宗祠は統宗祠、支祠へと分化したことが分る。

\section{7. 結論}

本研究では、宋代から明・清代にかけての地方志「新安志」、「徽州 府志」、禀県志」を中心とする史料を基に、龵県における祠堂建築の 地域性と分類、分布と分化・発展を検討した。

(1) 祠堂建築の分類は、㪟県においても古来の地縁的な地方信仰に 起源をもつ「祠廟」、祖先祭祀のための墓祭式の「墓祠」、廟祭式の「宗 祠」の 3 つに大きく分けられた。これらの祠堂建築の形成過程を時代 別に要約すれば(表 8 ) のように纏められる。祠廟・墓祠・宗祠につ いて、時代的な変遷を眺めると、南宋前の「祠廟」の成立期、南宋 以降の「墓祠」「宗祠」の発展期の 2 つに分けられ、これら 3 種の 祠堂建築は次のような特徵を備えていた。

ア）「祠廟」は、漢代から民間によって営まれた「専廟・専祠」 に始まり、唐代以降、朝廷に公認された人格神を祀る「廟・行祠」 が現れ、その後地方名士を祀る「祠・生祠」が誕生する。祠廟は、 祭祀対象が祭祀者の祖先に限定されず、親族以外の人物を祀る。

イ）「墓祠」は、漢代以来、墓の近くにあり、葬られている墓主 を祀るものであったが、龵県では宋・元代に入ると仏教・道教の影 響を受け、墓の近くに「墳寺・墳庵」を建てるものが現れた。また、 仏寺の中に祖先の墓祠を造る場合もある。

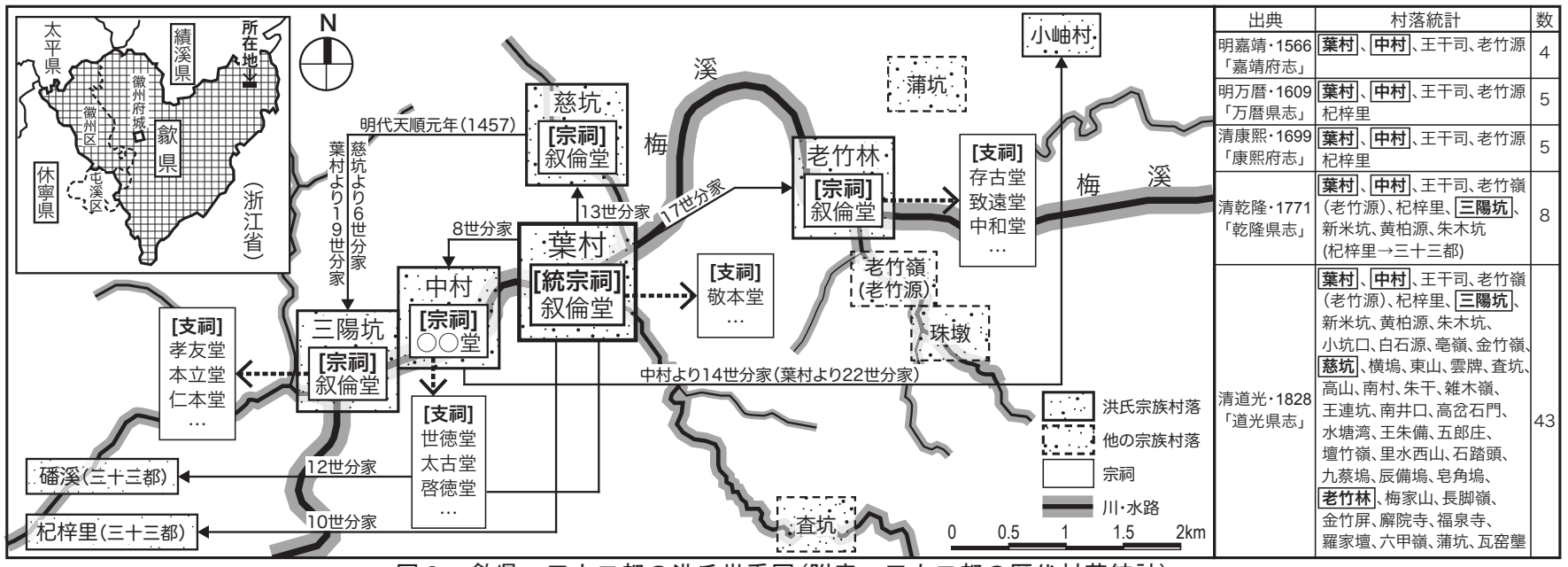

図 9 欹県・三十二都の洪氏世系図(附表 三十二都の歴代村落統計)

表 8 㰸県における祠堂建築の分類と時代区分

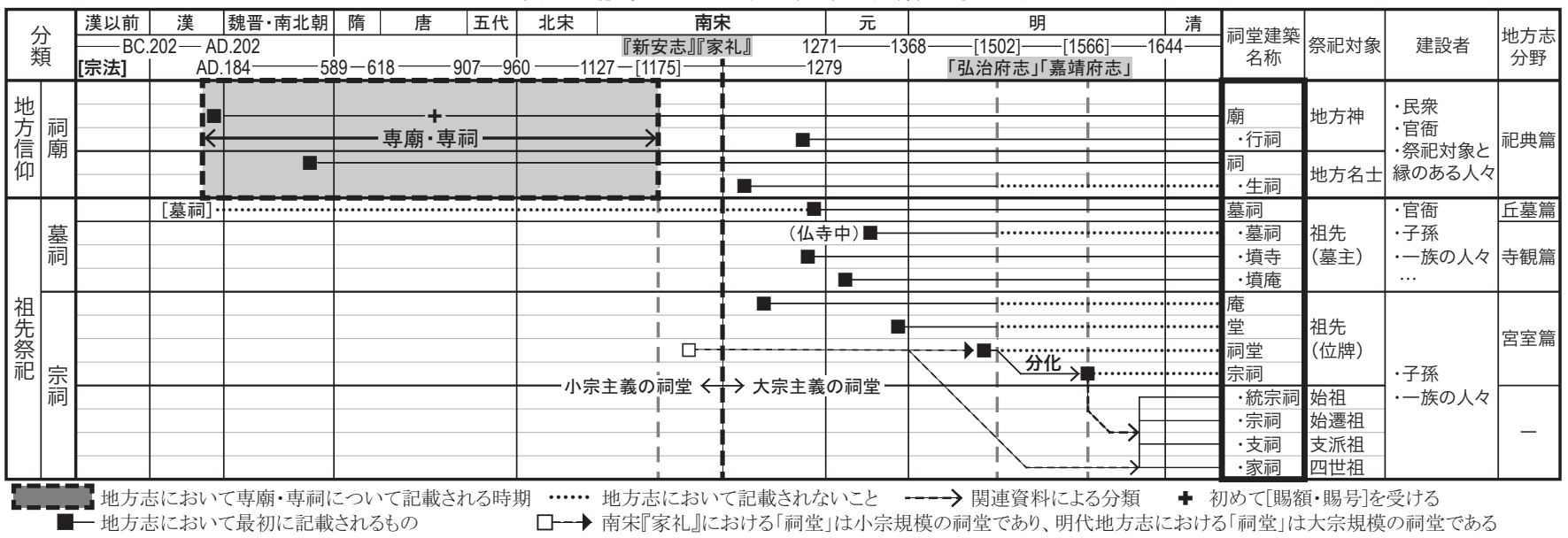


ウ）「宗祠」は、宋代の『家礼』によれば家族を中心とする祖先 祭祀を行い、小宗主義の「祠堂」から発展した。宋代以降宗族の形 成・組織化、明代中期の嘉靖年間の礼制改革などにより、宗族によ る大宗主義の祖先祭祀が数多く行われるようになり、䣄県において も宋代から明代中期にかけて「庵・堂・祠堂」などの宗族的な建物 が現れ、明代中期以降に「宗祠」が建てられるようになった。

(2) 祠堂建築の分布は、禀県では、祠廟が主に城内(隅) ・城外 (関廂) に集中していたが、商人たちの商業活動に伴う支援により、河川を 利用した水上交通路に沿って「廟」から「行祠」へと分化し、河川流域 に分散した。また、行祠の建設は、宗族に影響を与えたと見られ、 宗族村落の発展と共に「宗祠」が増加し、特に、明代嘉靖年間以降、 農村部 (鄉都)において宗祠が増加している。

(3) 宗祠の分化・発展は、顽県では明代に「庵・堂・祠堂」から「宗 祠」へと発展し、明代から清代にかけて「総宗祠・宗祠・支祠・家 祠」へと分化し、それらは以下のような性格を備えていた。

[統宗祠 $] \cdots$ 始 祖(最初の定住地の始遷祖) $\cdots$ 複数の宗族村落の祭祀

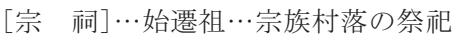

[支 祠 $] \cdots$ 支派祖 $\cdots$ 宗族村落の支派の祭祀

[ 家 $\quad$ 祠 $] \cdots$ 四世祖 $\cdots$ 宗族村落の家族の祭祀

このように、当地方では宗祠は宗族の相続・分家により、「統宗祠」 が中心となり、新たな宗族村落が生み出されると、「宗祠」さらにそ の下に「支祠」「家祠」などが建てられ、河川流域に遠心的に分布 する構図を築くことになった。

\section{参考文献}

1）鈴木博之: 明代における宗祠の形成, 集刊東洋学, Vol.71, pp.19-36, 1994.5

2）鈴木博之:徽州の村落と祠堂一明清時代の〔ブ〕源県を中心として一, 集 刊東洋学, Vol. 77, pp. 77-93, 1997.5

3) 常建華: 宋元時期徽州祠廟祭祖的形式及其変化, 徽学, 安徽大学徽学研究 中心, Vol. 1, pp. 38-51, 2001.6

4) 常建華: 明代宗族祠廟祭祖礼制及其演変, 南開学報 (哲学社会科学版), 2001 年版, No. 3, pp. 60-67, 2001. 5

5) 常建華: 明代墓祠祭祖述論, 天津師範大学学報 (社会科学版), 2003 年版, No. 4 , pp. $37-42,2003.8$

6) 井上徹: 中国の宗族と国家の礼制一宗法主義の視点からの分析一, 研文出 版, 2000.2

7）松本浩一:宋代を中心としてみた都市の祠廟の変遷, 都市文化研究, Vol. 4, pp. 127-142, 2004. 9

8）吾妻重二:宋代思想の研究一儒教・道教・仏教をめぐる考察一, 関西大学 出版部, 2009. 3

9) 白井佐知子: 徽州商人の研究, 汲古書院出版, 2005.2

10) Park Won-ho: 明清徽州宗族史研究一歎県方氏的個案研究 (中文修訂版), 中国社会科学出版社, 2009. 12

11）王鶴鳴, 王澄: 中国祠堂通論, 上海古籍出版社, 2013.4

12）安徽省黄山市文化委員会編: 黄山市徽州古建築保護工程名録, 黄山市文物 局に提供られた影印本, 2014.2

13) 中国国家文物局編: 中国文物地図集一安徽分册 (上) (下), 中国地図出版 社, 2014. 12

14）羅願 (編纂), 趙不悔 (修撰) : 新安志, 全十巻, 南宋淳熙二年, 1175 江舜民 (編纂), 彭澤 (修撰) : 徽州府志 (弘治府志), 全十二巻, 明代弘治十五 年, 1502

汪尚寧, 他 (編纂), 何東序, 他 (修撰) : 徽州府志 (嘉靖府志), 全二十二巻, 明 代嘉靖四十五年, 1566

趙吉士, 他 (編纂), 丁廷楗, 他 (修撰) : 徽州府志 (康熙府志), 全十八巻, 清代 康熙三十八年, 1699

馬歩蟾, 他 (編纂), 夏鑾, 他 (修撰): 徽州府志 (道光府志), 全十六巻図一巻,

清代道光七年, 1827

劉大槐, 他 (編纂), 張佩芳, 他 (修撰) : 翸県志 (乾隆県志), 全二十巻図一巻,
清代乾隆三十六年, 1771

沈伯棠, 他 (編纂), 労逢源, 他 (修撰) : 㰸県志 (道光県志), 全十巻図一巻, 清 代道光八年, 1828

15）謝陛 (編纂), 張涛 (主修) : 杽志 (万暦県志), 全三十巻, 明代万暦三十六年, 1608, 黄山書社出版, 2014.2

16）朱喜(輯録), 浅見安正 (校正): 家礼, 全五巻, 心斎橋通北久太郎町 (大阪), 積玉圃, 元禄十年, 1697

17）戴廷明,程尚寛, 他 (編纂) : 新安名族志, 前後巻, 明代嘉靖三十年, 1551, 黄 山書社出版, 2007. 12

注

注 1) 参考文献 14)，『新安志』を参照。

注 2) 参考文献 14)，『嘉靖府志』を参照。

注 3) 参考文献 14) は、北京図書古籍珍本叢刊, 書目文献出版社, 2000.7, 安徽 省地方志編纂委員辦公室に提供された影印本を利用した。

注 4) 参考文献 9) , p. 21，「徽州縣別概念図 (除教源縣)」を参照して作った。 注 5) 北京市文物研究所編: 中国古代建築辞典, 中国書店, 1992. 12, p. 180, 参照。 注 6) 参考文献 15), 孝巻三・志四・戸賦, p. 94，「商則即本郷者少 而外県之人

多」とあり、本籍に居る人より、客商として外地に赴いた商人が多かった。

注 7) 参考文献 9), p. 75, 参照。参考文献 14), 『嘉靖府志』, 第八巻 - 食貨志 四十二, p. 205, 「田少而直昂又生鹽日益盧舎墳墓不毛之地日多山峭水激濱 河被衝 鹽者多廃為沙磧不復成田 故中家而下皆無田可業 徽人多商賈蓋其 勢然也」とあり、徽州地方の田畑は少なく值段も高く、土地が塩化し易く、 水流も激し、農業に向かないため、人々は農業ではなく商業に向かった。 注 8) 参考文献 11), pp. 44-47，「周代的分封制和宗法制」を参照。

注 9) 参考文献 16) は、早稲田大学図書館・古典籍総合データベースに公開さ れている影印本を利用した。

注 10) 参考文献 16), 図○十八, p. 19,「大宗小宗図」を参照して作った。

注 11) 参考文献 7), pp. 128-129,「古代の社と祠廟への変化」を参照。

注 12) 参考文献 10), pp. 26-27, 「柳山方氏的徽州遷徙過程」を参照。

注 13) 参考文献 9), pp. 120-121，「汪氏の起源について」を参照。参考文献 14),

『新安志』第一巻 - 州郡篇 - 祠廟, pp. 23-24; 『弘治府志』巻之五・祀典篇 · 祠廟, pp. 33-49, 忠烈廟と忠烈行祠の事例を参照。

注 14) 参考文献 1), p. 30, 徽州府下の程氏の事例を参照。参考文献 14)，『弘治 府志』巻之五・祀典・祠廟, pp. 33-49, 世忠廟と世忠行祠の事例を参照。 注 15) 参考文献 11$)$, pp. $72-75$, pp. 80-83, 墓祠の論述を参照。

注 16) 参考文献 6), pp. 149-162，「『家礼』と宗法原理」の論述を参照。

注 17) 参考文献 6) , pp. 64-66, 大宗復活論 (大宗主義)を参照。pp. 64-66, p. 107, pp. 154-158, 小宗復活論 (小宗主義) を参照。

注 18) 参考文献 6), pp. 107-108，「始遷祖を始祖とする見解…」を参照。

注 19) 参考文献 6), pp. 178-197, 嘉靖年間の礼制改革とは、宗族形成運動に対 応する始祖祭祀の開放について、当時の礼部尚書・夏言が皇帝一上奏した。 その後、宗祠及び宗族の組織化が民間に普及したと指摘されている。

注 20) 祭祀対象が本研究と一致せず、外れた事例は以下の通りである。

『新安志』: 先聖廟 (儒家先聖)、岱岳廟 (泰山)、城隍廟 (城隍神)、霊順廟 (五 顕神)、孚恵廟 (神話・鳴山神)、浮丘先生廟 (神話・浮丘公)、霊山廟 (仏教 神・甘露王)、竅山廟 (竅山神)、計 8 件; 『弘治府志』: 城隍廟 (城隍神)、義 勇武安王廟 (関羽) 、東获廟 (泰山)、霊順廟 (五顕神)、玄壇廟 (道教神・玄壇 元帥)、龍王廟 (龍王)、張許二侯双廟 (唐代武将)、孚恵廟 (神話・鳴山神)、 張王廟 (張大帝)、霊山廟 (仏教神・甘露王)、竅山廟 (竅山神)、溪西昭明廟 (南 朝梁の皇族・昭明太子)、茅司徒廟 (神話・縛虎茅将軍)、計 13 件。

注 21) 参考文献 8), p. 152, 参照。専祠や専廟は、功績のあった人物や人格神を 祀り、当該人物ゆかりの地に建てられたと定義されている。

注 22) 参考文献 11), p. 248, 参照。参考文献 3), pp41-42, 徽州の『汪氏重修統 宗譜』巻四十一・「大畈端公祠記」に掲載される「別為専祠于大畈西浯村先 人故居 日永思堂 祀高祖而下四世 云々」とあり、子孫が祖先の旧宅を宗族 に寄進し、祖先祭祀の祠堂となったことが分る。

注 23) 参考文献 14), 『嘉靖府志』の図が不鮮明なため、『康熙府志』, pp. 95-96, 徽州府治城垣図, pp. 102-103, 剱県治城垣図を図 4 に載せている。

注 24) 城内には、寸でに宗代以前から官による祠廟が建てられており、明代 に宗族の祖先祭祀の制度が緩和されても宗祠を設立する余地が少なかった。 注 25) 表 7 に各姓の移住時代は、参考文献 17) と表 2 を参照。

注 26) 参考文献 11) , pp. 329-333, 参照。宗祠の堂号は、「某堂」と記される宗

族の発祥地、宗族の祖先の封号や諡号などの固有名詞である。

注 27) 参考文献 12), pp. 73-84, 10 件の家祠が掲載された。 


\section{STUDY ON RITUAL ARCHITECTURE IN HUIZHOU AREA, CHINA}

The classification and distribution of Ritual Architecture in Shē County

$$
\text { Yeqian } \text { ZHANG }^{*} \text {, Noboru SUGINO ** and Takiji SAWADA*** }
$$

\footnotetext{
* Grad. Stud., Dept. of Production and Construction Engineering Course, Graduate School of Engineering, Aichi Institute of Technology ** Prof., Dept. of Architecture, Aichi Institute of Technology, Dr.Eng.
}

*** Lect., Dept. of Architecture, Aichi Institute of Technology

The main objective of this research is use the basic data XinAn-Zhi, HuiZhouFu-Zhi, and SheXian-Zhi that local records from Sòng dynasty until Qīng dynasty to investigate classification, and regional distribution of Ritual Architecture in Shē county.

1. There's three types classification of Ritual Architecture. The first one is Regional Temple from local beliefs. Second one is Mausoleum has been made for ancestor worship. And third one is Ancestral Hall for Temple-worship. If we try to separate Regional Temple, Mausoleum and Ancestral Hall by transition according to age. Before Southern-Sòng Dynasty is Regional Temple's establishment period, and after Southern-Sòng Dynasty is Mausoleum, Ancestral Hall's progressive period. That three type of Ritual Architecture has their feature as below.

I . The Regional Temple came from Worthies-Shrine, Worthies-Temple run by private in Hàn dynasty. The Temple and Branch-Regional Temple were made for worship Personal God whom has been certified by government from Táng dynasty. After Táng dynasty, there is lot of the place has been used for worship local celebrity called Shrine or ShēngCí were created. The different between Regional Temple and Ancestral Hall is Ancestral Hall was only used for worship family ancestor, but Regional Temple can be used for worship normal people not just the family ancestor.

II. From Hàn dynasty, the place near by a grave was used for worship tomb owner of this grave called Mausoleum, and interpret by broad sense is the temple or the Hermitage has been built near by a tomb because some influence by Buddhism and Taoism from Sòng dynasty and Yuán dynasty, in Shē county. In addition, there's also some case to make the Mausoleum in the Buddhist temple.

III. Ancestral Hall was developed from Ritual Hall which built for ancestor worship by one family unit been called Minor-Descendants according JiaLi in Sòng dynasty. Since Sòng Dynasty along with Lineage's formation and organization, especially the ritual system reform in years of JiāJìng in Míng dynasty, Lineage ancestor worship of Major-Descendants became many. In addition, From Sòng Dynasty to the mid-Míng dynasty Lineage ancestor worship has been appeared in Hermitage, Hall or Ritual Hall, and after the mid-Míng dynasty it became to build Ancestral Hall in Shē country.

2. From Shē county's case to check distribution of Ritual Architecture, we know most of Regional Temple are around the city and move by merchant's travel on river, because that Branch-Regional Temple was be developed by Head-Regional Temple. In addition, Branch-Regional Temple also affected the Lineage, like Ancestral Hall's increase to follow Lineage's development. Especially, increase of Lineage's Ancestral Hall in Shē country was conspicuous from years of JiāJìng in Míng dynasty.

3. About brench and development of Ancestral Hall, Hermitage, Hall, and Ritual Hall develop to Ancestral Hall, and also divided to Total-Ancestral Hall, Head-Ancestral Hall, Branch-Ancestral Hall, Family-Ancestral Hall, from Míng dynasty to Qing dynasty. Every Ancestral Hall building has their property as below.

Total-Ancestral Hall --- The First Ancestor ---A Lineage-Group Settlements

Head-Ancestral Hall --- The First Immigration Ancestor ---A Lineage Settlement

Branch-Ancestral Hall --- The Ancestor of A branch --- A branch of Lineage Settlement

Family-Ancestral Hall --- Four-Generation Ancestor --- Family of Lineage Settlement

So, Shē county's Ancestral Hall accompanied by Lineage's continuation and branch, That Total-Ancestral Hall will be set up the center of a Lineage-Group Settlements, which surrounded by Head-Ancestral Hall, Branch-Ancestral Hall and Family-Ancestral Hall of a branch Lineage or Family. And, that we know these as telecentric along river distribution. 